\title{
Microbial contribution to post-fire tundra ecosystem recovery over the 21 st century
}

\section{Nicholas J. Bouskill ( $\nabla$ njbouskill@lbl.gov )}

Lawrence Berkeley National Laboratory https://orcid.org/0000-0002-6577-8724

\section{Zelalem Mekonnen}

Lawrence Berkeley National Laboratory https://orcid.org/0000-0002-2647-0671

\section{Qing Zhu}

Lawrence Berkeley National Laboratory

\section{Robert Grant}

University of Alberta

\section{William Riley}

Lawrence Berkeley National Laboratory

\section{Article}

Keywords: tundra ecosystems, soil microbiology, nutrient cycling

Posted Date: July 26th, 2021

DOI: https://doi.org/10.21203/rs.3.rs-734815/v1

License: (c) (i) This work is licensed under a Creative Commons Attribution 4.0 International License.

Read Full License

Version of Record: A version of this preprint was published at Communications Earth \& Environment on February 11th, 2022. See the published version at https://doi.org/10.1038/s43247-022-00356-2. 


\section{Microbial contribution to post-fire tundra ecosystem recovery over the $21^{\text {st }}$ 2 century}

Nicholas J. Bouskill ${ }^{1 *}$, Zelalem Mekonnen ${ }^{1}$, Qing Zhu ${ }^{1,2}$, Robert Grant ${ }^{3}$, William J Riley ${ }^{1}$

${ }^{1}$ Climate and Ecosystem Sciences Division, Lawrence Berkeley National Laboratory, Berkeley, CA, 94720.

${ }^{2}$ Berkeley Institute of Data Science, University of California, Berkeley, CA, 94720.

${ }^{3}$ Department of Renewable Resources, University of Alberta, Edmonton, Canada

*Contact: (njbouskill@address.gov)

Tundra ecosystems have experienced an increased frequency of fire in recent decades, and this trend is predicted to continue throughout the $21^{\text {st }}$ Century. Post-fire recovery is underpinned by complex interactions among microbial functional groups that drive nutrient cycling post-fire. Here we use a mechanistic model to demonstrate an acceleration of the nitrogen cycle post-fire driven by changes in niche space and microbial competitive dynamics. We show that over the first 5-years post-fire, fast-growing bacterial heterotrophs colonize regions of the soil previously occupied by slower-growing saprotrophic fungi. The bacterial heterotrophs mineralize organic matter, releasing organic and inorganic nutrients into the soil. This pathway outweighs new sources of nitrogen and facilitates the recovery of plant productivity. We broadly show here that while consideration of distinct microbial metabolisms related to carbon and nutrient cycling remains rare in terrestrial ecosystem models, they are important when considering the rate of ecosystem recovery post-disturbance and the feedback to soil nutrient cycles on centennial timescales.

\section{Introduction}

The vast organic matter stocks in arctic permafrost soils $\left(\sim 1,000 \mathrm{PgC}\right.$ in the top $\left.3 \mathrm{~m}^{1-3}\right)$ have the potential to contribute positively to rising atmospheric carbon dioxide concentrations and the carbon-climate feedback. Air temperatures in Arctic regions are currently warming at twice the global average rate $\left(0.6{ }^{\circ} \mathrm{C} \text { per decade }\right)^{4}$, which can stimulate microbial decomposition and accelerate the turnover of the soil organic matter (SOM) stocks to greenhouse gases $\left(\mathrm{CO}_{2}, \mathrm{CH}_{4}\right.$, and $\mathrm{N}_{2} \mathrm{O}$ ). However, rising air temperatures also drive increased drought ${ }^{5}$, higher vapor pressure deficits $^{6,7}$, and lightning ${ }^{8}$, contributing to an increased frequency and intensity of tundra fires ${ }^{9-11}$.

33 Fires represent a significant disturbance to high-latitude ecosystems. The aftermath of a fire alters the surface energy balance ${ }^{12}$; alters soil hydrodynamics ${ }^{13,14}$; reduces soil carbon stocks, including ancient carbon previously sequestered within permafrost ${ }^{15}$; increases soil nutrient losses ${ }^{16}$; and causes shifts in plant and microbial community composition ${ }^{17,18}$. Depending on fire severity and depth of the burn, fire ramifications on ecosystem thermal, chemical, and biological features can be apparent for several decades post-fire ${ }^{12,19}$. However, how abrupt disturbances, such as fire, shape ecosystem responses to climate change, including to soil carbon stocks, remains uncertain. 
Broad impacts of fire on tundra plant communities have been reasonably well characterized ${ }^{17,20-}$

${ }^{22}$, and differences in recovery have been demonstrated for vascular plants and cryptogams (e.g., moss and lichen) ${ }^{17}$. Shrubs and graminoids regenerate quite rapidly from soil seed banks, and increase in abundance post-fire ${ }^{21,23}$. However, the timescale for recovery differs between the two plant types, with rapid recovery shown for graminoids ${ }^{17}$, relative to shrubs, which can take more than a decade to reestablish ${ }^{22}$. However, fires have also been shown to elevate shrub expansion relative to pre-fire conditions, hastening transitions that would otherwise take decades ${ }^{22}$. Cryptogams, by contrast, have no fire survival strategies, and tend to be decimated by fire ${ }^{24}$. Their recovery is often very slow due to a need for recolonization post-fire via airborne spores originating from unburned regions.

Belowground, fire acts as a direct disturbance to microbial communities through heat-induced mortality and shifting community composition in the upper soil layers ${ }^{25-27}$. Fire also acts on the microbial community indirectly by changing nutrient availability ${ }^{28}$, and the quality and quantity of carbon sources ${ }^{29}$, shaping the metabolic diversity of belowground communities ${ }^{18}$. Microbes also differ in their sensitivity to fire and recovery post-fire, whereby bacteria recover more quickly relative to fungi ${ }^{27,30,31}$. However, Hewitt et al. ${ }^{32}$ noted that, while increasingly severe fire reduces the relative abundance of fungal taxa, mycorrhizal fungi can become more resilient to fire through the resprouting life-history of tundra shrubs maintaining an inoculum source postfire $^{32}$. Recovery of microbial communities post-fire is critical to organic matter decomposition and nutrient cycling and availability, which drives vegetation recovery. However, the sequence of events that facilitate a reversion to ecosystem steady-state post-fire, including the links between microbial and plant communities, remain difficult to demonstrate empirically. In addition to the effects of fire, shrub expansion under a warming climate ${ }^{33,34}$ can change the composition of belowground communities ${ }^{35}$. Shrubs tend to produce litter with higher carbon to nitrogen ratios, encouraging the growth of fungi with lower nitrogen requirements relative to bacteria $^{36}$. This pattern is important as the role fungi play in soil carbon cycling can be distinct from that of bacteria, partly because fungi produce chemically recalcitrant biomass, which slows rates of decomposition ${ }^{37}$. Therefore, climate-fire interactions that shape vegetation and microbial community composition will feedback on the tundra carbon cycle ${ }^{38,39}$.

70 Here we apply observations and a well-tested mechanistic model to address the question of how

71 disturbance from a tundra fire interacts with longer-term climate perturbations (i.e., warming, increasing $\mathrm{CO}_{2}$ concentrations, and elevated precipitation). We focus our model experiments on one of the largest tundra fires on record, the 2007 Anaktuvuk River Fire, Alaska, which was likely caused by lightning and exacerbated by record high summer temperatures and record low summer precipitation ${ }^{23,40,41}$. The present study simulates the ecosystem responses to, and recovery from, that fire. We initially parameterize and benchmark the model using the available data built up around this well-studied fire ${ }^{15,17,23,41,42}$. Once benchmarked, we conduct modeling experiments to address three main questions: (1) What are the long-term ramifications of fire disturbance against the backdrop of ongoing climate change across the $21^{\text {st }}$ century? (2) What role does the belowground microbial community play in enabling the recovery of the aboveground plant community? (3) How does recovery post-wildfire differ between an early $21^{\text {st }}$ century graminoid dominated ecosystem, and a late century shrub-dominated ecosystem with high shrub abundance?

\section{Results:}


We next describe: (1) model testing at the Anaktuvuk River site; (2) $21^{\text {st }}$ century carbon and nitrogen cycling in the absence of fire; (3) fire effects on $21^{\text {st }}$ century carbon cycling; (4) fire effects on $21^{\text {st }}$ century soil moisture and temperature; and (5) fire effects on $21^{\text {st }}$ century belowground microbial community structure and nutrient cycling.

Model testing at the Anaktuvuk River site: We evaluated the model against data collected from the severe 2007 Anaktuvuk River fire. Data was collected on plant community metrics ${ }^{17}$, soil carbon $^{15}$, and site physical factors ${ }^{23}$. Figure 1 shows agreement between measured and simulated values (normalized Root Mean Square Error $(\mathrm{RMSE})=0.037)$. The model replicated the annual net primary productivity (NPP) of the ecosystem before $\left(\sim 200 \pm 40 \mathrm{~g} \mathrm{~m}^{-2} \mathrm{yr}^{-1}\right)$ and 4 years after $\left(\sim 160 \pm 10 \mathrm{~g} \mathrm{~m}^{-2} \mathrm{yr}^{-1}\right)$ the fire. Further, the model performed well in replicating the NPP of individual PFTs (Fig. 1, S2a), with graminoids making up approximately $60 \%$ of the vegetation (observation: $\sim 125 \mathrm{gC} \mathrm{m}^{-2} \mathrm{yr}^{-1}$; simulation: $120 \pm 40 \mathrm{gC} \mathrm{m}^{-2} \mathrm{yr}^{-1}$ ) prior to fire, and shrubs accounting for most of the remainder (observation: $75 \mathrm{gC} \mathrm{m}^{-2} \mathrm{yr}^{-1}$; simulation: $75 \pm 20 \mathrm{gC} \mathrm{m}^{-2} \mathrm{yr}^{-}$ ${ }^{1}$; Fig. S2a). Non-vascular plants were present but represented a small ( $\left.3 \%\right)$ fraction of NPP in observations and the simulation. Pre-fire total (to $0.2 \mathrm{~m}$ depth) soil carbon content reported for this site ranged from $2,842 \mathrm{gC} \mathrm{m}^{-2}$ to nearly $20 \mathrm{kgC} \mathrm{m}^{-2}$ (depending on the depth of the soil organic layer, which ranged from 12.3 to $43.3 \mathrm{~cm}$ ). The simulated pre-fire $0-20 \mathrm{~cm}$ depth soil carbon content is $6,320 \pm 355 \mathrm{gC} \mathrm{m}^{-2}$, which is consistent with a reported value of $7682 \pm 766$ $\mathrm{gC} \mathrm{m}^{-2}$ from $0-21.5 \mathrm{~cm}$ depth $^{15}$. Total modeled soil carbon concentration from $0-1 \mathrm{~m}$ depth was $42.3 \mathrm{kgC} \mathrm{m}^{-2}$. Finally, thaw depth pre- and post-fire was accurately modeled compared to 105 the observations (Fig.1, S2b).

106

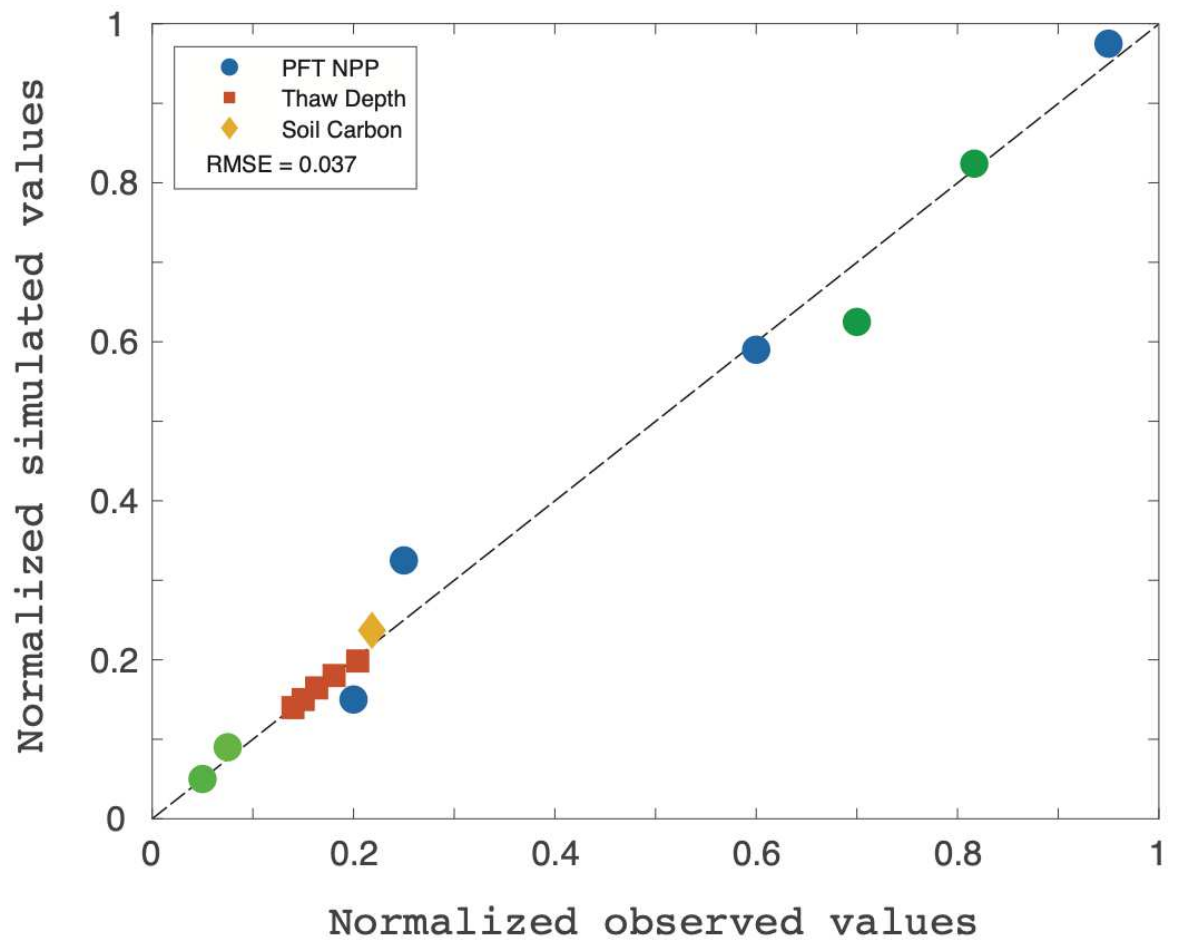


Figure 1: The model runs were benchmarked by comparison to observational data taken before and either one or four years after the 2007 Anaktuvik severe fire. The benchmarks include net primary productivity (total and PFT specific), active layer depth pre- and post-fire, and soil carbon stocks. The NPP data are separately reported for the unburned ecosystem (blue circles) and post-fire plots (green circles). For ease of visualization, the figure provides comparisons between the normalized data; individual benchmark comparisons are provided in the supplemental material (Figs. S2).

116 These results, and previously described evaluations of the model against diurnal, seasonal, and 117 inter-annual variability of high-latitude ecosystems with $^{39}$ and without fire ${ }^{43-46}$, and the review of previous comparisons provided above, demonstrate that ecosys provides a reasonable representation of tundra ecosystems, and can be extended to our $21^{\text {st }}$ century model experiments.

$21^{\text {st }}$ century carbon and nitrogen cycling in the absence of fire: We first evaluated the site responses under the baseline RCP8.5 scenario (Table 2), which did not have fire. Over the $21^{\text {st }}$ century the site NPP more than doubled, from $\sim 200 \mathrm{gC} \mathrm{m}^{-2} \mathrm{yr}^{-1}$ to $\sim 530 \mathrm{gC} \mathrm{m}^{-2} \mathrm{yr}^{-1}$ (Fig. 2a), and despite a large increase in ecosystem respiration (heterotrophic + autotrophic) became a stronger net sink for atmospheric carbon (Fig. 2b). Increased shrub abundance and growth, particularly of evergreen shrubs, were simulated throughout the $21^{\text {st }}$ century and accounted for much of the elevated NPP by 2100 .

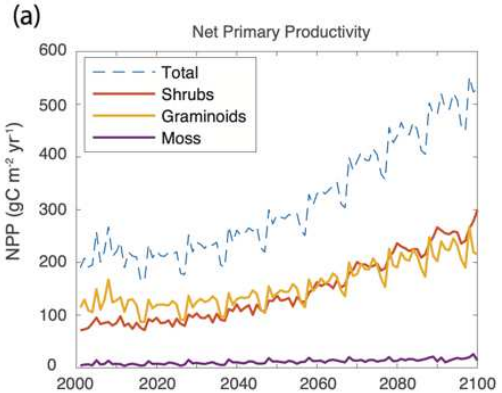

(c)

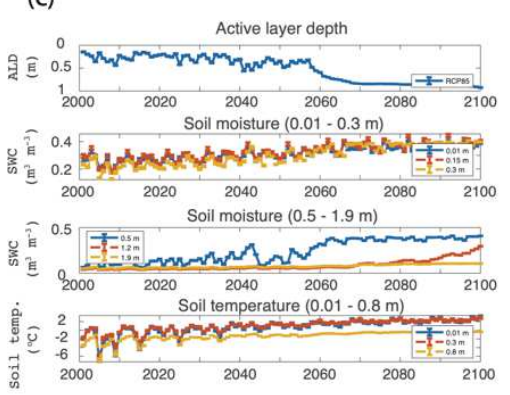

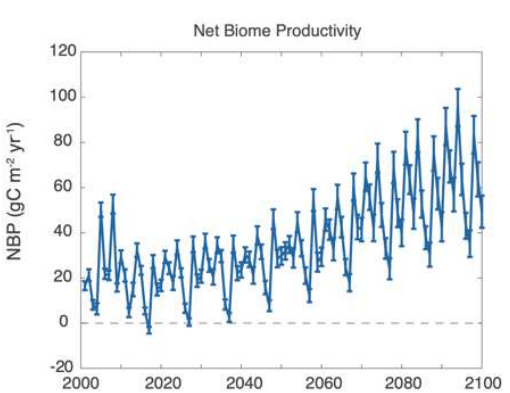

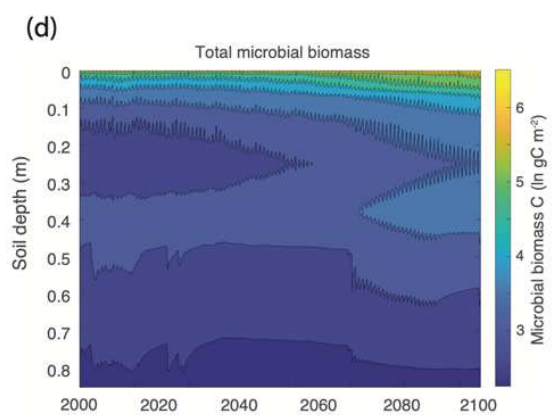

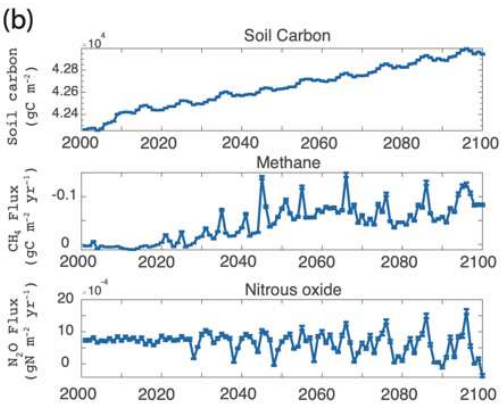

(e)

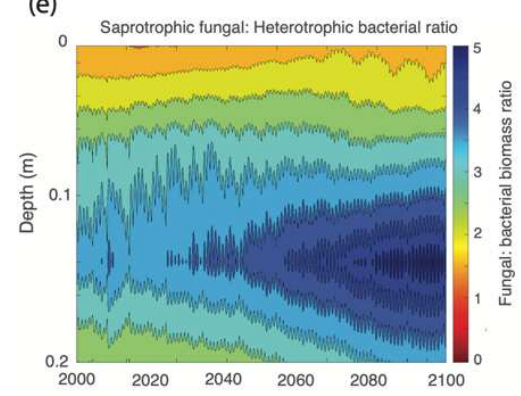

130 Figure 2: Ecosystem trajectories under the baseline RCP8.5-no fire scenario for the period 2000 to 2100 . The panels show (a) changes in net primary productivity $\left(\mathrm{gC} \mathrm{m}^{-2}\right)$ for the total plant ecosystem and by plant functional type, (b) net biome productivity $\left(\mathrm{gC} \mathrm{m}^{-2} \mathrm{yr}^{-1}\right)$, (c) soil carbon stocks $\left(\mathrm{gC} \mathrm{m}^{-2}\right)$ and methane $\left(\mathrm{gC} \mathrm{m}^{-2} \mathrm{yr}^{-1}\right)$ and nitrous oxide $\left(\mathrm{gN} \mathrm{m}^{-2} \mathrm{yr}^{-1}\right)$ fluxes, (d) physical and hydrological responses. The panels depict (from top to bottom), the active layer depth (m), soil 
moisture in surface soils at 0.01-0.3 $\mathrm{m}$ and deeper down $(0.5-1.9 \mathrm{~m})$ depths $\left(\mathrm{m}^{3} \mathrm{~m}^{-3}\right)$, and soil temperature $\left({ }^{\circ} \mathrm{C}\right)$ at three soil depths $(0.01,0.3$ and $0.8 \mathrm{~m}),(\mathrm{e})$ total microbial biomass down to $0.85 \mathrm{~m}$ depth (units of $\ln \mathrm{gC} \mathrm{m}^{-2}$ ), and ( $\mathrm{f}$ ) the biomass ratio of saprotrophic fungi to heterotrophic bacteria (aerobic + facultative heterotrophs) in the top $20 \mathrm{~cm}$ of soil.

Consistent with the stronger ecosystem sink by 2100 , soil carbon slightly increased over time, accumulating $\left(0.67 \mathrm{kgC} \mathrm{m}^{-2} ; 1.5 \%\right)$ by 2100 . Methane emissions increase over the $21^{\text {st }}$ Century but remained low, while nitrous oxide $\left(\mathrm{N}_{2} \mathrm{O}\right)$ production generally becomes more variable over time (Fig. 2b), alongside an increase in soil nitrogen concentrations, yet does not show a clear trajectory of increasing emissions. The active layer depth increases slowly to $50 \mathrm{~cm}$ at year 2060 before deepening more rapidly to $\sim 90 \mathrm{~cm}$ by the end of the century. Corresponding increases in soil moisture were simulated, with a slow increase in the shallower soil (surface to $\sim 0.3 \mathrm{~m}$ depth), and a rapid increase at approximately $0.5 \mathrm{~m}$ in line with a drop in the ALD (Fig. 2c). Towards the end of the century, as the ALD deepens beyond $1 \mathrm{~m}$, soil moisture at depth also increases rapidly. Soil temperature demonstrates a similar response, increasing over time from an annual average of $-2{ }^{\circ} \mathrm{C}$ within surface soils, to a temperature of $+3{ }^{\circ} \mathrm{C}$ by the end of the century (Fig. 2c).

Increasing thaw depth, soil carbon, temperature, and moisture provided additional niches for growth and activity of microorganisms. Over the $21^{\text {st }}$ Century under the RCP8.5 scenario, microbial biomass increased (Fig. 2d), notably within surface soils, but also at depth $(>0.5 \mathrm{~m})$ concurrent with increasing thaw depth. Within the $0-0.2 \mathrm{~m}$ depth interval, much of the simulated increases were attributable to increasing fungal biomass, concordant with increasing shrub biomass and a lower litter quality ( $\mathrm{C}: \mathrm{N}$ ratio), that resulted in a higher fungal:bacterial biomass ratio over time (Fig. 2e).

The transfer entropy approach adopted here identifies the most important factors leading to the annual increases in simulated ecosystem NPP. Notably, nutrient cycling and plant assimilation are critical to plant NPP throughout the century (Fig. S3a/b). Additional factors contributing to increased NPP include increased snowpack depth, soil moisture, and soil temperature. These factors all contribute to increased root and mycorrhizal growth and microbial mineralization responsible for nutrient release.

Fire effects on $21^{\text {st }}$ century carbon cycling: We next evaluated how pulsed perturbation (fires of various severities) impact this tundra ecosystem under a continuing RCP8.5 press perturbation (climate change). These fire perturbations were applied during two timeframes: (i) early in the century (during 2007) under a graminoid-dominated ecosystem, and (ii) later in the century (in 2080) when woody shrubs dominate ecosystem biomass. Fire prescribed in both 2007 and 2080 significantly reduced soil carbon stocks through combustion by a maximum of $\sim 2,400 \mathrm{gC} \mathrm{m}^{-2}$ under the severe fire conditions, and less under moderate $\left(1400 \mathrm{gC} \mathrm{m}^{-2}\right)$ and mild $\left(550 \mathrm{gC} \mathrm{m}^{-2}\right)$ severity fires (Fig 3). The severe fire modeled values are consistent with observed values of net carbon loss of $2,016 \mathrm{gC} \mathrm{m}^{-2}$ measured a year following the actual Anaktuvik severe 2007 fire $^{15}$. The recovery of modeled soil carbon stocks in the 20 years post-fire showed clear differences between fires initiated in 2007 and in 2080, and between fires of different severity. Following a fire of mild-severity ignited in 2080 soil carbon stocks equilibrated to pre-fire conditions after 8 years, and thereafter exceeded initial conditions (Fig 3b). By contrast, soil carbon stocks burned in all the other fire simulations did not return to pre-fire conditions 20 years post fire (Fig $3 a$ ). 
However, soil carbon stocks following late-century moderate and severe fires rebounded to their new quasi-steady condition more rapidly than those following early century fires.

Soil carbon stock recovery post-fire

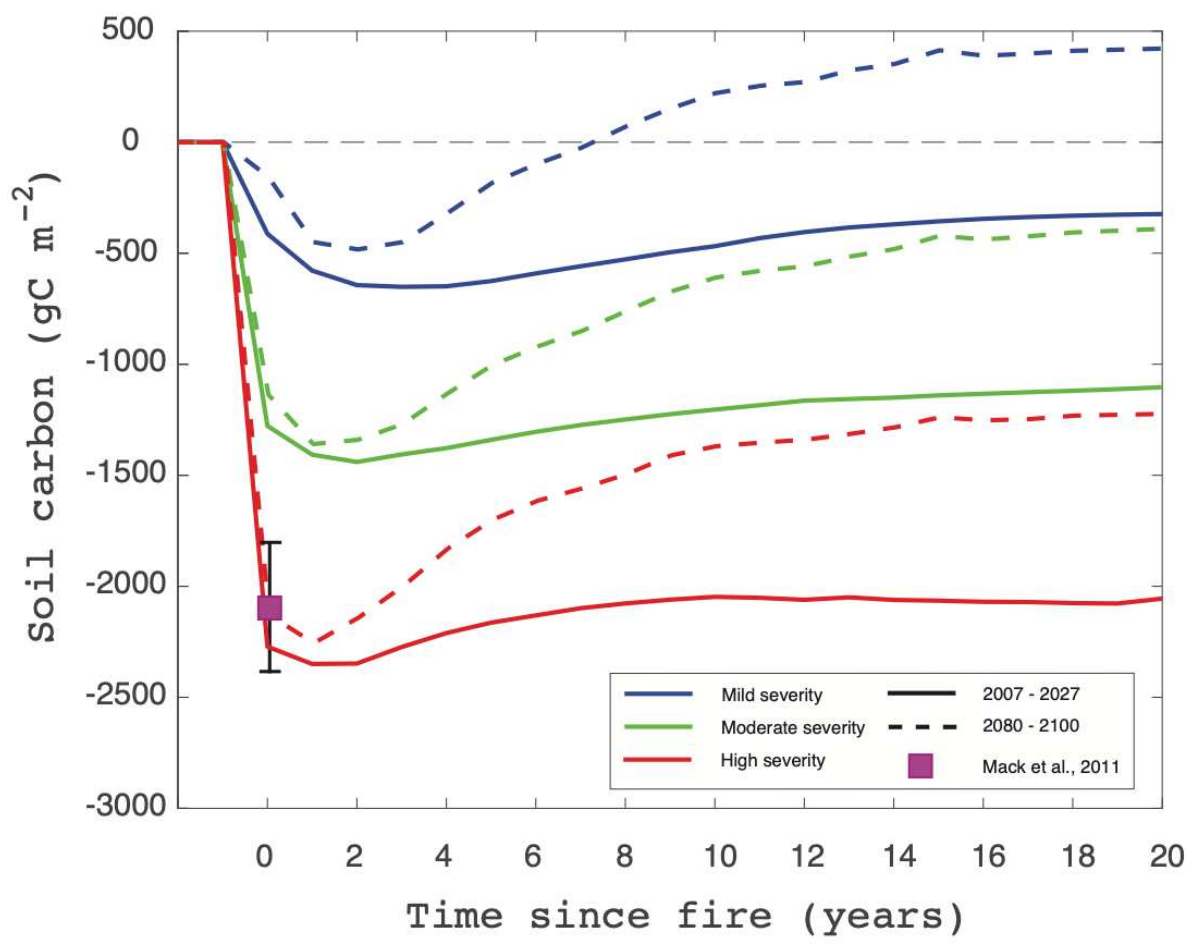

183 Figure 3: Total soil organic carbon loss $\left(\mathrm{gC} \mathrm{m}^{-2}\right)$ and recovery trajectory for the period 20 years post-fire. The panel shows both the fire initiated in 2007 (solid lines) and the fire initiated in 2080 (dashed lines). For comparison, the carbon loss measured by Mack et al. (2011), under the actual severe Anaktuvik tundra fire is illustrated, showing very good consistency with the modeled value in the prescribed high-severity fire scenario.

188 Net primary productivity decreased more strongly following late- than early-century fires (Fig. 189 4a). Notably, the post-fire recovery in the case of mild and moderate 2007 fires matched pre-fire 190 NPP by 2060. The severe-fire NPP remained below pre-fire levels for the remainder of the $21^{\text {st }}$ 191 Century. In both the early-century fire scenarios, graminoids led the post-fire plant community 192 recovery, and in the year following fires comprised nearly all of the vegetation productivity (Fig. 193 4b.i, ii). Shrubs re-established more slowly in the case of both early- and late-century fires (Fig. 194 4b). Under the early-century fire scenario, shrub expansion occurred earlier than under the 195 baseline RCP8.5 scenario without fire, and dominated community composition to a greater 196 extent by the end of the $21^{\text {st }}$ Century, particularly under the severe fire scenario. The moss PFT 197 was decimated by the fire, and took nearly 30 years to re-establish as a contributor to community 198 NPP. In the case of the late-century fires, graminoids dominated the reestablished community, 199 while shrubs, in contrast to the early-century simulations, took almost a decade to re-establish. 
(a)

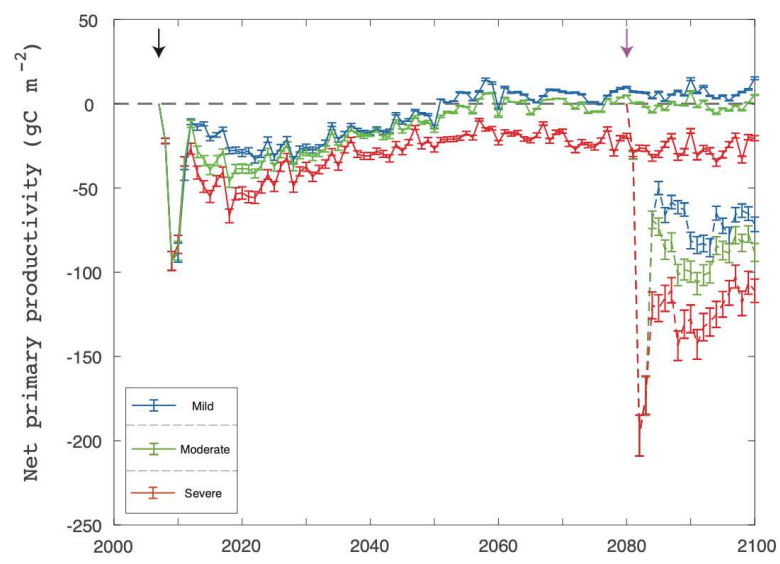

(b)
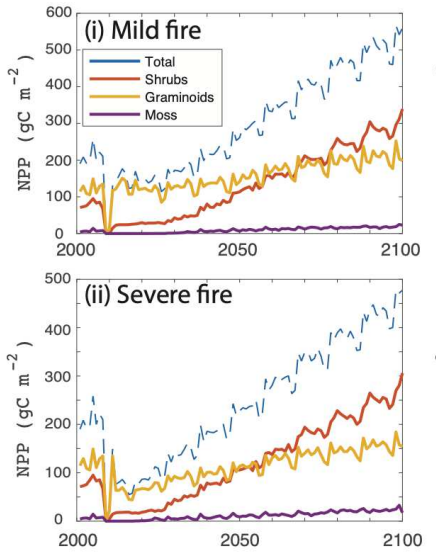
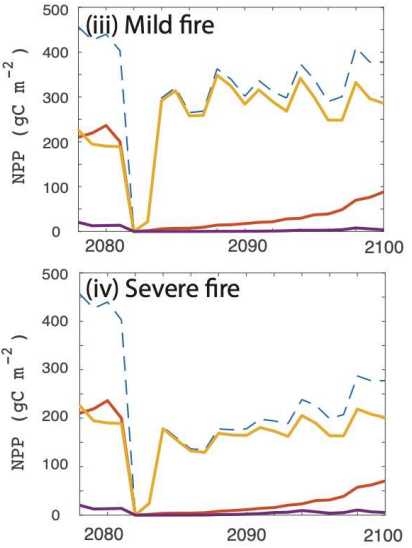

Figure 4: Net primary productivity $\left(\mathrm{gC} \mathrm{m}^{-2} \mathrm{yr}^{-1}\right)$ post-fire under different scenarios of fire severity and timing. Panels show the total NPP (annual mean \pm standard error) difference from the baseline run under the RCP8.5 scenario. (a) NPP responses under mild, moderate, and severe fires. (b) broken down by plant functional type for (i) a mild, and (ii) severe fire initiated in 2007, and for a (iii) mild and (iv) severe fire initiated in 2080. Changes in PFT NPP for panels (iii) and (iv) cover years 2080 - 2100 (i.e., the 20 years post-fire).

The transfer entropy approach identified several factors that contributed to the post-fire recovery of community NPP (Fig. S3b, c), some of which differed from the factors identified under the baseline RCP8.5 scenario, and differed between the early- and late-century fires. Notably, nutrient availability and uptake is critical for re-establishment of vegetation post-fire (Fig. S4). Nutrient availability depends on soil moisture and temperature (particularly in the surface soil), which promotes the activity of several microbial groups decomposing organic matter, thereby liberating nitrogen and phosphorus. Furthermore, nitrogen fixation increases in all cases following fire (see below). For early-century fires, NPP is influenced by snowpack depth and active layer depth, which affects post-fire nutrient cycling. NPP recovery following late-century fire is sensitive to changes deeper in the soil profile, including soil moisture and temperature at depths greater than $0.5 \mathrm{~m}$, indicating that nutrient acquisition that aids NPP recovery occurs from deeper in the soil profile (Fig. S4).

Fire effects on $21^{\text {st }}$ century soil moisture and temperature: ALD deepened by up to $0.2 \mathrm{~m}$ in the 8 years following an early century fire (Fig. S5). However, over the first two years post-fire the ALD was shallower than the baseline RCP8.5 scenario. Mean annual soil moisture and temperatures also increased, and remained higher than the baseline even as the active layer deepened over the following years (between 2- and 8-years post-fire). These thaw depth dynamics are consistent with data collected at the Anaktuvuk River site post-fire. Modeled soil moisture and temperature maintain dynamic responses for several years post-fire and before stabilizing a decade after a fire (Fig. S5a). Indeed, excursions from the RCP8.5 scenario in the ALD, soil moisture, and temperature are also apparent for the next two decades following the fire. 
231 Despite a much deeper active layer by 2080, the onset of fire caused a consistent deepening of 232 ALD (Fig. S5b), which continued for two decades following the fire. This deepening was 233 particularly notable under the most severe fire, where ALD deepened $0.2 \mathrm{~m}$ by 2100 . Much 234 smaller differences between fire severity scenarios were modeled for soil moisture and 235 temperature. However, fire caused annual fluctuations through 2100 in soil moisture and 236 temperature relative to the baseline RCP8.5 scenario.

237 Fire effects on the $21^{\text {st }}$ century soil microbial community and nutrient cycling: The simulated 238 changes in vegetation, soil hydrology, and temperature discussed above result in changes in the 239 structure of the belowground microbial community. Notably, fire reduces the abundance of 240 saprotrophic fungi by $\sim 30 \%$ between 5 and $20 \mathrm{~cm}$ depth, vacating a niche that the fast-growing 241 heterotrophic bacteria fill (Fig. 5). Within warmer, more nutrient-rich shallow $(0-5 \mathrm{~cm})$ soils, a 242 long-term change in microbial composition is noted, whereby the heterotrophic bacteria 243 dominate the microbial community over the next century, under both the mild and severe fire 244 scenario (Fig 6a). However, deeper into the soil profile $(\sim 10 \mathrm{~cm})$ heterotrophic bacteria are 245 outcompeted by saprotrophic fungi 10 years post fire (Fig. 6b). The decline in saprotrophic fungi 246 following the end-of-century fire prompts the rapid growth of heterotrophic bacteria taking 247 advantage of the elevated organic matter and nutrient availability (Fig. 5.iii/iv). This rapid 248 change in community composition decreases the community $\mathrm{C}: \mathrm{N}$ ratio from an average of $\sim 8.5$ 249 to 6.6, indicative of a microbial community dominated by bacteria (Fig. S6). The rapid growth of 250 the heterotrophic bacteria and subsequent SOM decomposition releases inorganic nitrogen and 251 phosphorus (Fig. S7b, S8b), and encourages the growth of autotrophic and heterotrophic 252 organisms involved in nutrient cycling. 

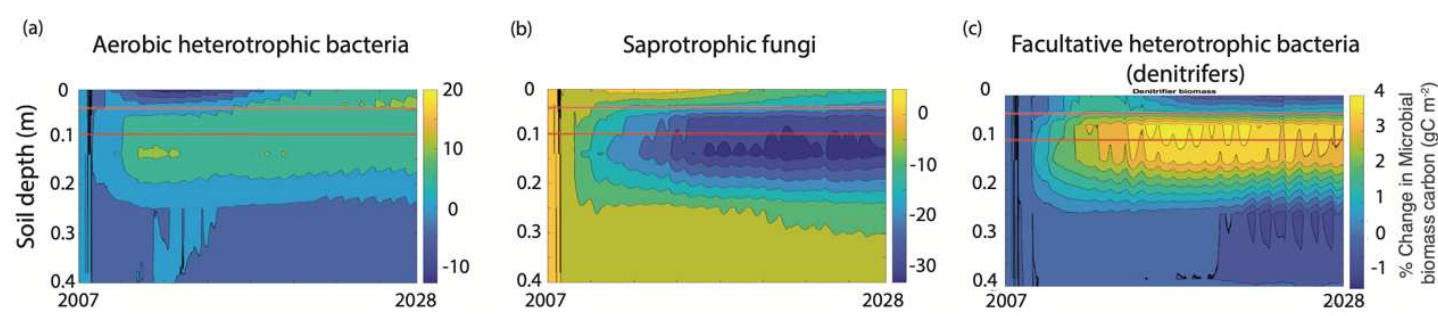

(i) Mild fire (2007-2028)
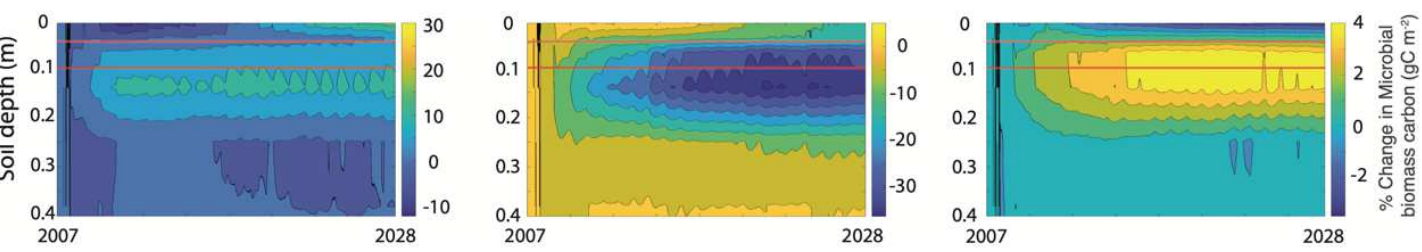

(iii) Mild fire $(2078-2100)$
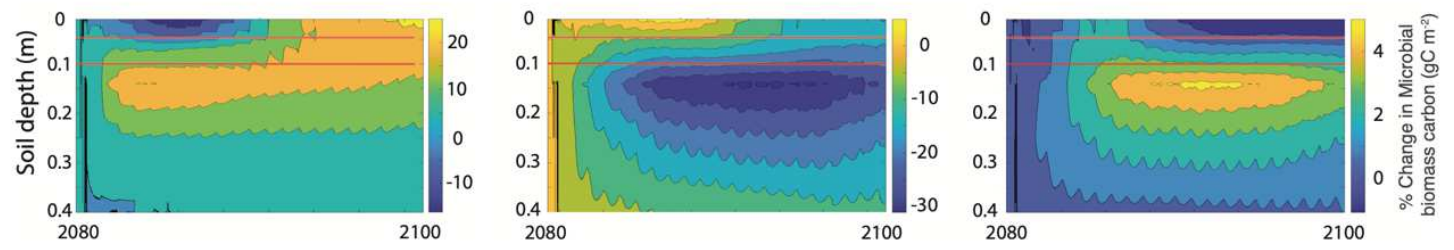

(iv) Severe fire $(2078-2100)$
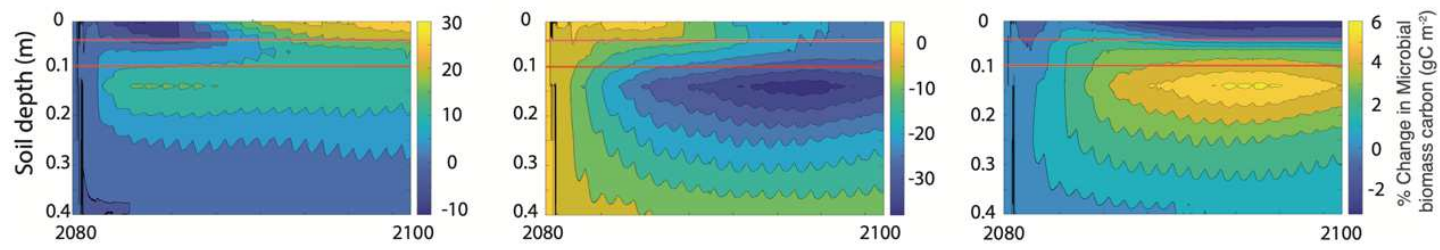

Figure 5: Percentage change in microbial biomass carbon (each column shows a different microbial functional group) under the four $21^{\text {st }}$ century fire scenarios, and long-term trajectory of the heterotrophic community (bacteria + fungi). In the contour plots in columns (a) - (c), the colors represent the percent change in microbial biomass relative to the baseline RCP8.5-no_fire simulations. Depicted are the 20 years post fire for (i) the mild fire scenario and (ii) the severe fire scenario between $2007-2028$, and (iii) the mild fire scenario and (iv) the severe fire scenario between 2078 - 2100. Note: the percentage change color bars are specific to each panel. The red lines in each contour figure represent the depths depicted in figure 6. 
(a)

(i) Mild fire (2007 - 2028)

(ii) Severe fire (2007 - 2028)

(iii) Mild fire (2078 - 2100)

(iv) Severe fire (2078 - 2100)
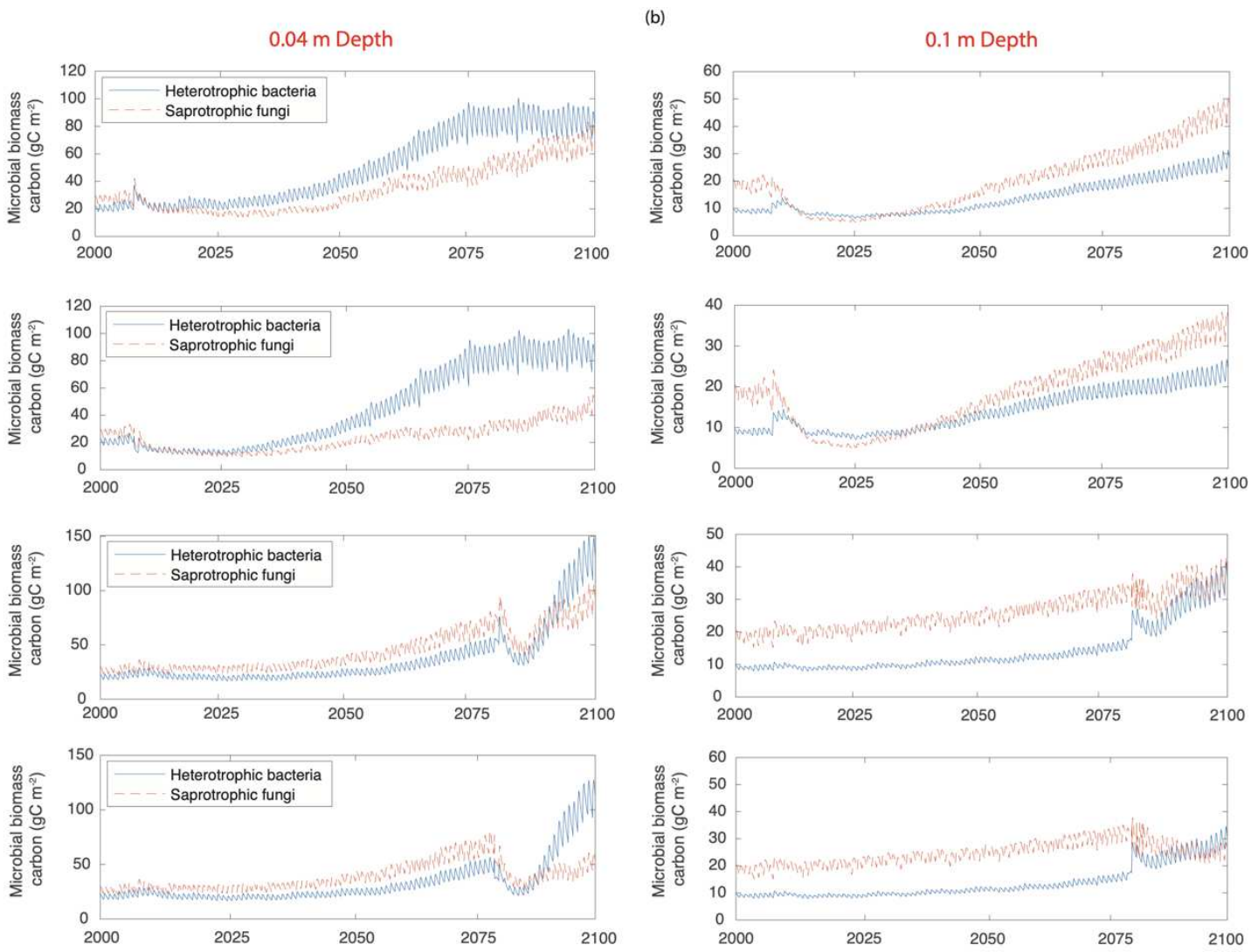

Figure 6: The trajectory of the microbial biomass $\left(\mathrm{gC} \mathrm{m}^{-2}\right)$ at two different depths, (a) 4 and (b) $10 \mathrm{~cm}$ depth between 2000 and 2100, respectively. As for figure 5, depicted are the 20 years post fire for (i) the mild fire scenario and (ii) the severe fire scenario between 2007 - 2028, and (iii) the mild fire scenario and (iv) the severe fire scenario between $2078-2100$.

Fire creates conditions that lead to ecosystem nutrient losses through $\mathrm{NH}_{3}$ volatilization and runoff of nitrogen and phosphorus species that would have ordinarily been retained in microbial or plant biomass (Fig. S7, S8). These losses drive selection for microbial groups involved in catalyzing the input and transformation of different nitrogen species, as noted by a post-fire peak in their abundance, in particular in abundance and distribution of diazotrophic bacteria (Figs. 7). Lower nitrogen inventories provide a niche for diazotrophic bacteria capable of fixing atmospheric nitrogen to $\mathrm{NH}_{4}{ }^{+}$. The diazotrophs showed the largest relative increases and spatial colonization, post fire, relative to other N-cycling groups (Fig. 7). These responses occurred regardless of fire severity or timing of fire onset (i.e., early or late century, Fig. 7). However, fire severity and timing impacted the recovery of nitrogen-fixation post-fire. For example, a mild severity fire early in the century showed a rapid return to pre-fire nitrogen fixation rates (Fig. S9), however, a severe fire at the same time point shows no recovery of nitrogen fixation to prefire levels in the two decades post-fire (Fig S9b). By contrast, following a severe fire late in the century (ignited in 2080), nitrogen fixation not only recovers quickly but also increases beyond nitrogen fixation rates within unburnt soils. 
The elevated diazotrophic biomass persisted for longer than both the $\mathrm{NH}_{4}{ }^{+}$- and $\mathrm{NO}_{2}{ }^{-}$-oxidizing functional groups. However, in the decades following fire, the biomass of all nitrogen cycling organisms generally declined (Fig. 7). This trend was consistent with the baseline RCP8.5-nofire scenario, which showed a decline in biomass of nitrogen-cycling organisms (Fig. 7b). This decline was arrested by the ignition of a late-century fire, which open the niche for nitrogen cycling functional groups. The elevated activity of diazotrophs and soil bacterial heterotrophs increased soil $\mathrm{NH}_{4}{ }^{+}$concentrations (Fig. S7b), which stimulated $\mathrm{NH}_{4}{ }^{+}$-oxidation and, in turn,

$294 \mathrm{NO}_{2}{ }^{-}$-oxidizing bacteria. The accumulation of $\mathrm{NO}_{3}^{-}$is subsequently denitrified.

(a)

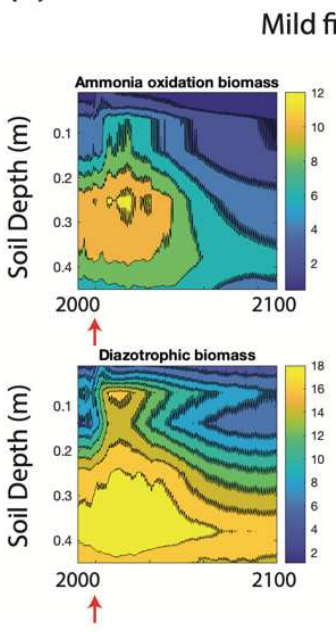

(b)
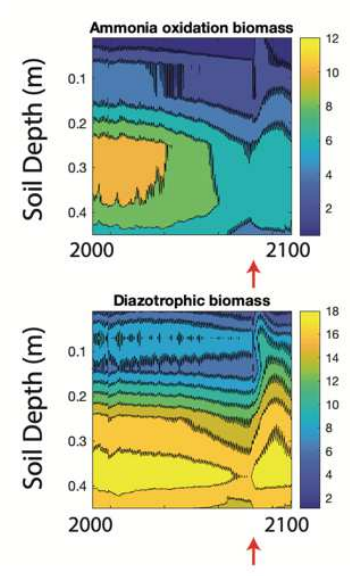

Early century fire initiated in 2007

Severe fire scenario
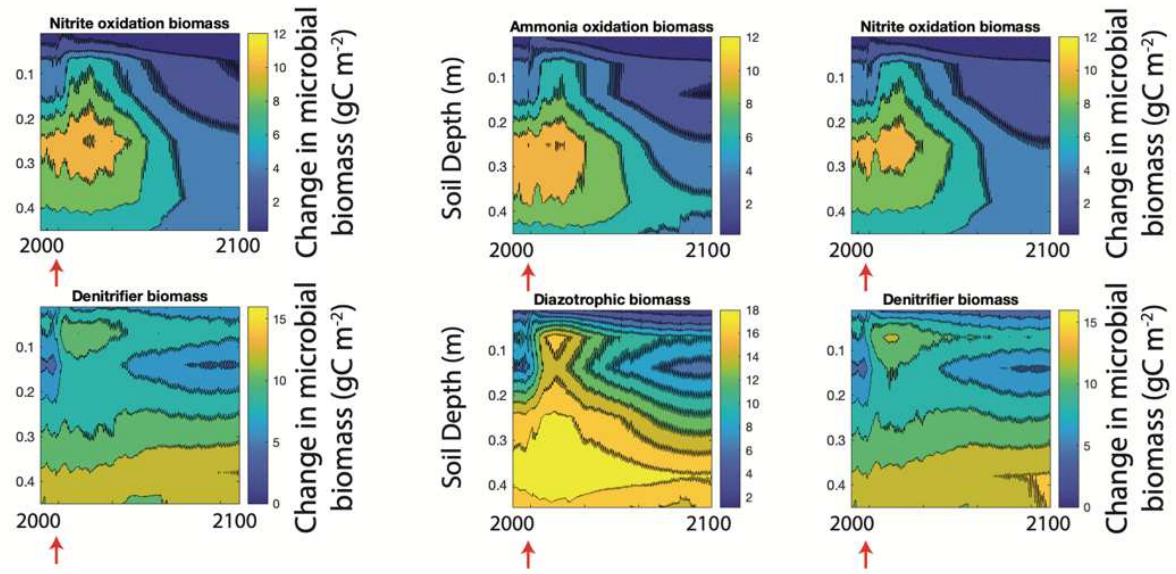

Late century fire initiated in 2080
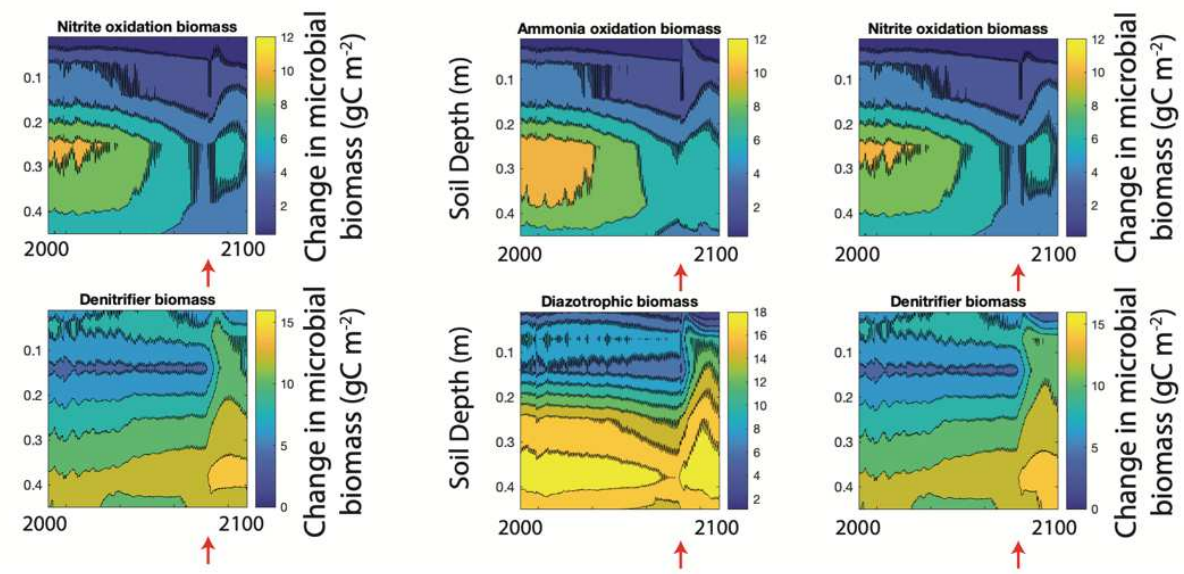

297 Figure 7: Changes relative to the baseline RCP8.5-no_fire scenario in the biomass $\left(\mathrm{gC} \mathrm{m}^{-2}\right)$ of nitrogen cycling organisms, $\mathrm{NH}_{4}^{+}$and $\mathrm{NO}_{2}{ }^{-}$oxidizers, facultative denitrifying bacteria, and 299 diazotrophic bacteria under different fire scenarios for the period spanning 2000-2100. Panels show the same depth range $(0-0.45 \mathrm{~m})$ and temporal scale $(2000-2100)$ for the mild fire severity (left side), and the severe fire (right side panels). Panels depict (a) biomass of four 
over the RCP8.5 simulations until the onset of fire in 2080. Red arrows along the x-axis indicate the year fire was initiated. The biomass of each organism represents the difference between the

(a)

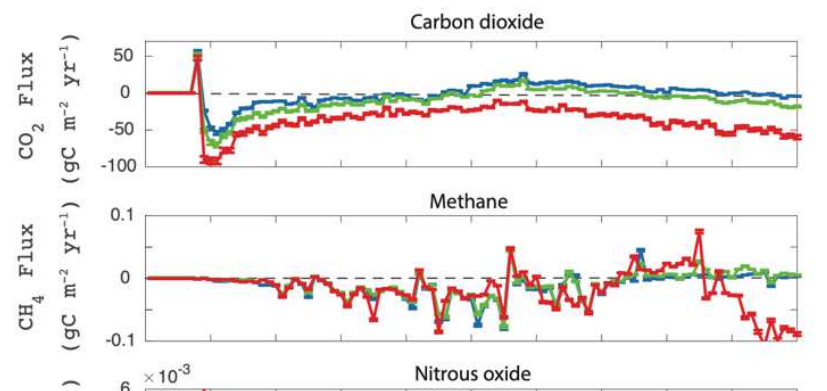

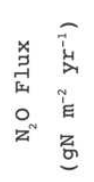
gas fluxes represent emissions from the soil.

\section{Discussion:} underlying mechanisms responsible for these dynamics. (b)
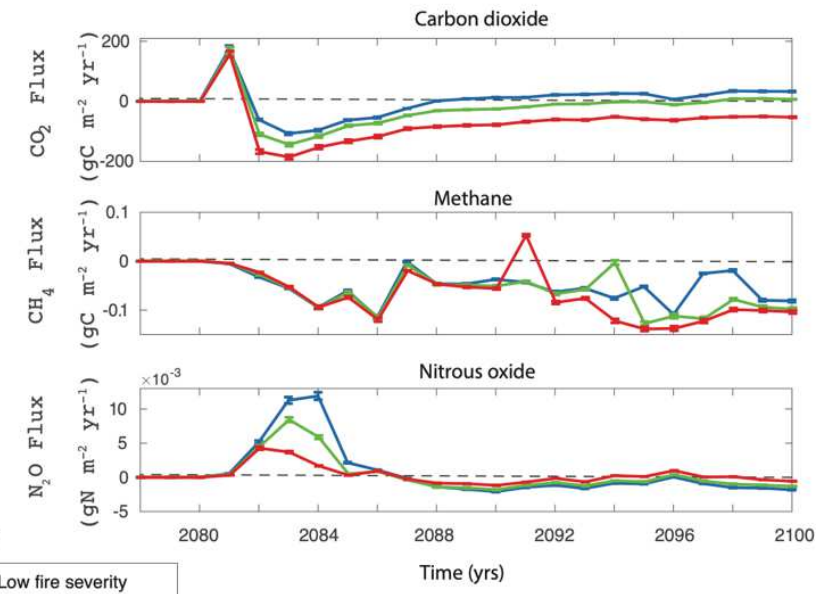

- Low fire severity

Moderate fire severity High fire severity

Figure 8: Trace gas fluxes under the six fire scenarios for (a) early-century fire (ignited in 2007), and (b) late-century fire (ignited in 2080). Gas fluxes $\left(\mathrm{CO}_{2}, \mathrm{~N}_{2} \mathrm{O}, \mathrm{CH}_{4}\right)$ were normalized to the baseline RCP8.5-no fire simulation to depict the impact of fire. Note that the timescales for panels (a) (years 2000 - 2100) and (b) (years 2075 - 2100) are different. Note: positive values for

High-latitude tundra systems face an unprecedented increase in fire frequency and intensity over the $21^{\text {st }}$ Century coupled to ongoing climate warming ${ }^{8,47}$. Each fire event represents an acute disturbance to the tundra landscape, and leads to large soil carbon losses ${ }^{15}$, long-term shifts in vegetation and microbial community composition ${ }^{18,20,22,32}$, and soil hydrology and temperature. However, the intensification of fire events occurs against a backdrop of ongoing climate change $\mathrm{e}^{48,49}$, and the future impact of climate on ecosystem responses to fire disturbances remains a critical knowledge gap. Herein, we used observations from the 2007 fire at Anaktuvuk River, Alaska, as the basis for evaluating model performance and developing model simulations to examine how disturbance from fire affects long-term changes in ecosystem dynamics, soil microbial processes, and tundra carbon cycling. We then use the model algorithms to explore the

Long-term climate responses: In the absence of fire, model simulations predict the site will remain a carbon sink throughout the $21^{\text {st }}$ Century under an RCP8.5 climate scenario. This result is consistent with pan-Alaska ${ }^{50}$ and pan-Arctic simulations ${ }^{51}$ that, despite regional differences, predict a continuing carbon sink within the Arctic over the next 100 years. These modeled 
carbon sinks are maintained by a large non-linear increase in NPP over the century, which offsets elevated heterotrophic respiration. The elevated NPP is predominantly attributable to the growth of graminoids and a growing contribution of evergreen and deciduous shrubs, particularly after 2060. Shrub expansion is attributable to elevated air temperature and increased soil nutrient availability ${ }^{35}$. The latter stems from increased organic matter depolymerization and mineralization under warming soils that release both nitrogen and phosphorus ${ }^{52}$. Furthermore, warming and increased soil moisture can deepen the active layer, the latter through increasing thermal conductance ${ }^{46}$ and precipitation heat content ${ }^{53}$. A deepening active layer can enhance microbial decomposition of newly accessible organic matter ${ }^{54}$ and release previously frozen inorganic and organic nutrients, which can be assimilated by tundra plants ${ }^{55-57}$ directly and through mycorrhizal symbiont ${ }^{58}$. Indeed, nutrient uptake from permafrost soils has previously been shown to promote a shift in community composition from graminoid-dominated towards shrub-dominated ecosystems ${ }^{59}$.

However, while there exists observational evidence ${ }^{33,34,60}$ and model simulations ${ }^{43}$ for the expansion of shrubs across tundra ecosystems, the majority of these studies attribute the expansion to deciduous shrubs, such as dwarf shrubs or willow ${ }^{34}$. At the northern Anaktuvuk River site, evergreen shrubs were observed and modeled to be significant contributors to ecosystem biomass and NPP at the beginning of the $21^{\text {st }}$ century ${ }^{17}$, and modeled to increase over time. The simulated evergreen shrub expansion is consistent with recent studies ${ }^{61,62}$, and could be attributable to relatively low nutrient availability at this site relative to other tundra ecosystems, which favors the more conservative strategy of evergreen shrubs ${ }^{35,63}$. In ecosys, evergreen shrub traits imply a more conservative plant functional type (PFT) that are slower growing and have slower leaf turnover. In contrast, deciduous shrubs have more rapid leaf turnover, higher nutrient uptake capacity, and more efficient nutrient remobilization, all of which produce competitive advantages under more nutrient rich conditions. In previous work, we found that deciduous shrubs emerge as the dominant shrub further south in Alaska ${ }^{39}$.

This shift towards an evergreen shrub dominated ecosystem is relevant as they play contrasting ecological roles relative to deciduous shrubs ${ }^{63,64}$. While taller deciduous shrubs increase snow depth $^{65}$, which can potentially accelerate carbon cycling ${ }^{66,67}$, evergreen shrubs do not deepen snowpack, produce more recalcitrant litter, and have been predicted to increase soil carbon stocks, feeding back negatively on climate change ${ }^{64}$.

Long-term climate-fire interactions: Measured and modeled post-fire recovery of the plant community occurred rapidly. Graminoids, in particular, recover rapidly following fire, almost reverting to pre-fire NPP a few years later. While the lack of competition from evergreen and deciduous shrubs likely facilitates this recovery, increased nitrogen and phosphorus availability immediately following the fire alleviates nutrient limitation, at least temporarily, allowing for more rapid recovery of these PFTs with traits that lead to more rapid nutrient uptake and thereby growth. This mechanism has support from measurements following the Anaktuvuk River site fire $^{17}$ and observed initial increases in graminoid abundance within nutrient fertilization experiments ${ }^{68}$. Shrubs take longer to re-establish in the years following fire relative to graminoids. However, for severe fires occurring earlier in the century, enhanced shrub growth (i.e., evergreen + deciduous shrubs) was modeled to occur approximately 5 years earlier than under the RCP8.5-no_fire scenario, and notably, shrub growth is far quicker towards the end of the century. Under the RCP8.5-no_fire scenario, shrubs contribute more to community NPP than 
graminoids by 2100 ( $52 \%$ from shrubs, $44 \%$ from graminoids). By contrast, after the onset of a severe fire early in the century, shrubs contribute $64 \%$ of community NPP, relative to $31 \%$ contributed by graminoids by 2100 . The mild-severity fire did not result in enhanced shrub growth. However, by 2100 , the contribution of shrubs to community NPP increased relative to graminoids (58\% from shrubs, $40 \%$ from graminoids) under both early-century fire severity scenarios. Similar responses in shrub expansion have previously been observed following tundra fire under similar conditions to those modeled here ${ }^{8,22}$.

The factors influencing modeled NPP recovery show commonalities between fires of different severity occurring over the same time period (i.e., either at the beginning or the end of the $21^{\text {st }}$ century). The most important variables supporting NPP recovery, as identified by our information entropy approach, include soil moisture content, nutrient availability, and plant nutrient assimilation (Fig. S4). While these factors are likely coupled, nutrient availability is a strong control on primary productivity in tundra communities ${ }^{68,69}$. A large loss of nutrients, which can occur post-fire as a result of combustion, increased run-off, or volatilization ${ }^{16,70,71}$, can slow ecosystem recovery within these nutrient limited systems. We modeled large dissolved inorganic nitrogen losses, primarily in post-fire runoff, alongside more moderate concentrations of dissolved organic nitrogen. How ecosystems reestablish nutrient cycling post-disturbance is critical to the recovery of ecosystem function and maintaining a balance between plant assimilation and microbial transformation ${ }^{72}$.

The role of belowground communities in ecosystem recovery: Several studies have developed conceptual theories concerning ecosystem recovery from disturbance ${ }^{72-74}$. For example, Rastetter et al., ${ }^{72}$ identify three distinct phases in ecosystem recovery that are underpinned by nutrient availability. This framework encompasses the transition through quasi-steady states post-disturbance towards a steady-state. The initial recovery is largely dependent on the openness of the nutrient cycles, which determines the proportion of nutrients passed from soils to vegetation rather than being exported.

400 Our simulations show that hydrological and gaseous nitrogen losses are at their highest in the years after fire disturbance, indicating an open nitrogen cycle in the absence of vegetation. This dynamic is consistent with the first stage of ecosystem recovery ${ }^{72}$ whereby vegetation assimilation remains low during regrowth. A more open nitrogen cycle is also consistent with observations of nutrient export made at burned and unburned regions across the Anaktuvuk site $^{70}$. Combustion of aboveground and belowground biomass diminishes competition between vegetation and the microorganisms that rapidly colonize the burned soils. In the years following fire, bacterial heterotrophs (i.e., aerobic + facultative) dominate OM mineralization after most of the saprotrophic fungi is burned away. This successional pattern has ramifications for the rate of carbon and nutrient cycling. In ecosys, relative to the fungal saprotrophs, bacterial heterotrophs have faster growth rates and a lower $\mathrm{C}: \mathrm{N}$ biomass, resulting in a higher rate of OM turnover and lower necromass contribution to organic matter accumulation. These modeled traits also facilitate the heterotrophic competitive advantages early in succession. Such a shift is consistent with a recent conceptual framework that hypothesizes consistency between plant and microbial responses to fire, notably with an initial post-fire colonization by fast-growing bacteria ${ }^{75}$.

Vegetation recovery following fire is facilitated by nitrogen and phosphorus made available by bacterial heterotrophic mineralization of existing soil organic matter. In nitrogen-limited tundra, with low inputs through atmospheric deposition and nitrogen fixation ${ }^{76}$, recycling of organic 
matter and release of inorganic nutrients is the dominant pathway through which nutrients are made available for plant assimilation ${ }^{77}$. Diazotrophic microorganisms also respond rapidly following fire, increasing in biomass across the soil profile. However, nitrogen fixation remains far too low to account for the large modeled increase in soil nitrogen post-fire, and annual rates of nitrogen fixation are approximately two orders of magnitude lower than the post-fire peak in $\mathrm{NH}_{4}{ }^{+}$availability. This is consistent with recent observations ${ }^{78,79}$ that conclude that nitrogen fixation is a minor contributor to balancing the nitrogen cycle after tundra disturbances. In our simulations, diazotrophic abundance increased following fire because of their facultative capabilities. While diazotrophs are modeled to fix nitrogen when it is scarce, they retain the capacity to take it up from the surrounding environment when available ${ }^{80}$. Following fire, modeled diazotrophs benefit from reduced competition for nitrogen from plants and fungi, and expand their niche by fixing nitrogen while also assimilating available $\mathrm{NH}_{4}{ }^{+}$following mineralization.

431 Increasing $\mathrm{NH}_{4}{ }^{+}$concentrations post-fire also stimulates nitrification, increasing the production of more mobile $\mathrm{NO}_{3}{ }^{-} . \mathrm{NO}_{3}{ }^{-}$accumulation in the soil is ephemeral because it is rapidly lost hydrologically and subject to uptake by tundra plants ${ }^{81}$. Observations support the modeled increase in nitrification rates following fire ${ }^{82-84}$. Our simulations also suggest a long-term disturbance to the nitrogen cycle, whereby nitrification is elevated for several decades following fire, consistent with observations from ecosystems that are not adapted to stand-replacing fires ${ }^{83}$. The drop in nitrifying microbial biomass occurs as competition for $\mathrm{NH}_{4}{ }^{+}$increases concomitant with vegetation growth, as the ecosystem transitions towards a quasi-steady state as nutrient cycles close, and a balance between plant assimilation and microbial immobilization is reached.

Ecosystem response to early-century fire: Despite a modeled NPP recovery following fire consistent with observations ${ }^{17}$, the full recovery of vegetation NPP and biomass takes several decades under mild fire conditions, and did not fully recover under the severe early-century burn scenario by 2100 . This impact on vegetation is reflected in the soil carbon stocks, which do revert to pre-disturbance levels by 2100 under all modeled early-century fire severity scenarios. Soil nutrient accumulation post-fire continues over the century; however, nitrogen concentrations remain lower than under the climate-only scenario, showing that fire results in a long-term deficit of nitrogen. Furthermore, tundra ecosystems continue to lose inorganic nitrogen hydrologically over the century following a severe fire (Fig. S7). These results suggests that a steady state in nitrogen balance takes more than a century to attain for these ecosystems, although the modeled increases in inorganic nitrogen losses later in the century also interact with warming increased decomposition rates and nutrients losses. Indeed, Mack et al., ${ }^{15}$ estimated that the Anaktuvuk River fire caused the loss of 400 years of accumulated ecosystem nitrogen. Our simulations show that replenishment of such nitrogen stocks could be further compromised by a warming climate.

Ecosystem response to late-century fire: The ecosystem that burns in 2080 is notably different from the 2007 landscape in two main regards. First, as discussed earlier, shrub abundance (in terms of contribution to total biomass and NPP) increased over the century, and is slightly higher relative to the graminoids by 2080 . Second, and related to the elevated shrub abundance, soil nitrogen and phosphorus concentrations are significantly elevated by 2080. Large increases in 461 soil nutrient concentrations stem from several pathways. First, the mineralization of organic matter within the shallow soil is enhanced by increasing soil and air temperatures ${ }^{85,86}$. Second, 
modeled abrupt deepening of the ALD after 2060 exposed ancient organic matter previously sequestered in permafrost, which can be rapidly mineralized, yielding nutrients that are available for plant uptake ${ }^{55}$. Third, the model predicts an increasing snowpack depth over the century, and the resulting higher winter soil temperatures (from $\sim-9^{\circ} \mathrm{C}$ in 2000 to $\sim 0^{\circ} \mathrm{C}$ in 2080) encourage microbial growth and activity throughout the winter time, which has previously been shown to be an important time period for the release of nutrients ${ }^{87,88}$ and uptake by plants ${ }^{89}$. In addition to faster, more open nutrient cycles in the late $21^{\text {st }}$ Century, a notable relative decline in soil moisture occurs $\sim 3$ years following fire, which permits further oxygenation of the soil, thereby increasing microbial activity ${ }^{90}$. The accelerated nitrogen cycle that emerges towards the end of the century and higher availability of inorganic nitrogen leads to larger $\mathrm{N}_{2} \mathrm{O}$ emissions post-fire. The highest $\mathrm{N}_{2} \mathrm{O}$ emissions $\left(1.3 \times 10^{-2} \mathrm{gN} \mathrm{m}^{-2}\right)$ occur under a mild fire scenario, which limits the combustion of the microbial community and leads to a prolonged period of wetter soil, creating a niche for denitrifying organisms.

The higher pre-fire nutrient concentrations at the end of the century partly explain the more rapid recovery of the vegetation community to disturbance. Under these circumstances, an equilibrium between microbial immobilization and vegetation nutrient demand is reached quickly, facilitating the restoration of soil carbon stocks following a mild fire within two decades. Plant communities following fire are dominated by graminoids, with a slower recovery of shrub communities. Compared with the early-century simulations, shrubs increase more rapidly as a proportion of the total vegetation community the decade following a fire due to elevated nutrient availability selecting for plants with higher nitrogen use efficiency, allowing for higher carbon fixation relative to nitrogen uptake.

Conclusion: The simulations presented here clearly show microbially-dependent nutrient controls on the recovery of tundra ecosystems and progression of community development postfire. These microbial and plant successional trajectories are strong functions of competitor dynamics represented in ecosys. The ramifications of early-century fire persist for several decades post-fire and shape vegetation community development and the balance of nutrient losses and retention. However, over the next century, tundra warming will likely accelerate soil nutrient cycling, increasing nutrient availability, and hastening ecosystem recovery. Ignoring microbial dynamics, and plant-microbe interactions, likely increases the uncertainty of tundra carbon cycle interactions with climate change.

\section{Materials and Methods}

Model description and set-up: To address the preceding questions we apply a well-tested mechanistic ecosystem model, ecosys, which simulates the interdependent physical, hydrological, and biological processes that govern ecosystem responses to perturbation. The model, which includes mechanistic representations of carbon, water, nitrogen, and phosphorus dynamics in plants and soils, has been successfully applied in dozens of sites around the world, with many studies focusing on high-latitude ecosystems $s^{44,46,50,53,91}$. Further information on model structure and performance in tundra ecosystems is available in the supplementary materials. Below we outline some of the model features that are pertinent to the current study. 
Microbial community structure: Microbial communities are represented in ecosys as eleven distinct functional groups across each modeled soil layer ${ }^{92-94}$. The composition of the microbial community is affected by competition between the functional groups, which represent a collection of different traits related to substrate acquisition and the thermodynamics of different metabolisms. Aerobic heterotrophic bacteria and saprotrophic fungi couple decomposition of the DOC pool to $\mathrm{O}_{2}$ as a primary electron acceptor, which drives heterotrophic respiration $\left(R_{h}\right) . R_{h}$ can be constrained by soil temperature and soil water content (see below), $\mathrm{O}_{2}$ and substrate respiration $\left(R_{m}\right)$ dependent on microbial stoichiometry $(\mathrm{C} \cdot \mathrm{N})$ and soil temperature $R_{h}$ in excess of $R_{m}$ is used in growth respiration $\left(R_{g}\right)$, whereby the energy yield $(\Delta \mathrm{G})$ drives the growth of biomass (M) from substrate uptake according to the energy requirements of biosynthesis. Finally, microbial mortality $\left(D_{m}\right)$ occurs either under a first order decay rate, and when $R_{m}$ is in excess of $R_{h}$. Microbial biomass (M) is determined by the difference between DOC uptake and loss from $R_{m}, R_{g}$, and $D_{m}$.

Alternative electron acceptors are also represented in the model, whereby $R_{h}$ not coupled to $\mathrm{O}_{2}$ proceeds through the sequential reduction of nitrate $\left(\mathrm{NO}_{3}^{-}\right)$to gaseous nitrogen $\left(\mathrm{N}_{2}\right)$ (i.e., denitrification: $\mathrm{NO}_{3}{ }^{-} \rightarrow \mathrm{NO}_{2}{ }^{-} \rightarrow \mathrm{N}_{2} \mathrm{O} \rightarrow \mathrm{N}_{2}$ ), or the reduction of organic carbon through fermentation or acetotrophic methanogenesis. Of these anaerobic bacteria, the denitrifying bacteria are represented as facultative anaerobes (i.e., able to utilize both $\mathrm{O}_{2}$ and reduced $\mathrm{N}$ compounds as electron acceptors). The rate limiting step of the redox nitrogen cycle is represented as a two-step chemolithoautotrophic reaction whereby ammonium $\left(\mathrm{NH}_{4}{ }^{+}\right)$is oxidized to nitrite $\left(\mathrm{NO}_{2}{ }^{-}\right)$, which is oxidized to $\mathrm{NO}_{3}{ }^{-}$. $\mathrm{N}_{2} \mathrm{O}$ is a potential byproduct of this pathway under circumstances where the two components of the reaction are uncoupled. The $\mathrm{NH}_{4}{ }^{+}$that initiates the nitrogen cycle is provided through new sources of $\mathrm{N}$, atmospheric deposition or nitrogen fixation, or recycled nitrogen from organic matter $(\mathrm{OM})$ mineralization. Free-living diazotrophs are represented by both aerobic and anaerobic bacteria, which allocate $R_{g}$ partially towards the fixation of atmospheric $\mathrm{N}_{2}$. Methane $\left(\mathrm{CH}_{4}\right)$ production and oxidation are represented in the model by hydrogenotrophic and acetoclastic methanogens and chemolithoautotrophic methane oxidizers.

Within the soil environment all microbial groups seek to maintain minimal stoichiometric ratios (i.e., C:N or C:P) through the mineralization and uptake of dissolved organic nitrogen (DON), and phosphorus (DOP), $\mathrm{NH}_{4}^{+}, \mathrm{NO}_{3}^{-}$, and $\mathrm{H}_{2} \mathrm{PO}_{4}^{-}$, thus competing with plant roots and mycorrhizal uptake and affecting soil solution concentrations of these compounds. Free-living diazotrophs fix aqueous $\mathrm{N}_{2}$ under conditions where assimilation of $\mathrm{N}$-compounds is insufficient to maintain their minimal $\mathrm{C}: \mathrm{N}^{80}$.

$\mathrm{OM}$ in each soil layer is represented by several OM-microbial complexes of various thermodynamic favorability and availability to microbial heterotrophs ${ }^{95}$. Of particular relevance to this study are the two SOM pools denoted 'active' and 'passive'. The active pool is further resolved into components of variable thermodynamic potential; protein, carbohydrate, cellulose, and lignin. The passive SOM pool represents mineral-OM interactions, and is divided into two pools representing compounds reversibly sorbed onto mineral surfaces ${ }^{96}$, and those stabilized onto surfaces. Sorption to mineral surfaces is calculated by a Freudlich isotherm. Microbial decomposition products (e.g., C, N, or P) from organic matter-microbial complexes are gradually stabilized into more recalcitrant organic compounds with lower $\mathrm{C}: \mathrm{N}$ and $\mathrm{C}: \mathrm{P}$ ratios. Products 
from lignin hydrolysis combine with some of the products of protein and carbohydrate

The parameter values for each group are provided in supplementary material, however, in qualitative terms heterotrophic bacteria growing on simple DOC compounds while using $\mathrm{O}_{2}$ as an electron acceptor generally increase in biomass faster than other bacteria due to a larger energy yield from the redox reaction. By contrast, facultative anaerobes such as denitrifiers grow at a slower rate than obligate aerobes when using $\mathrm{O}_{2}$ as an electron acceptor, due to intracellular trade-offs that permit growth coupled to the reduction of different nitrogen compounds. Fungi show similar thermodynamic energetics to heterotrophic bacteria in terms of decomposition of organic compounds using $\mathrm{O}_{2}$ as an electron acceptor, but a slightly lower efficiency of biomass production, and a higher metabolic stoichiometry ${ }^{97}$.

Finally, in addition to soil nutrient availability, the growth and activity of the microbial functional groups are further constrained by soil temperature and soil water content ${ }^{94}$. Microbial substrate hydrolysis and oxidation by heterotrophic groups is sensitive to soil temperature according to a modified Arrhenius function with upper and lower temperature constraints ${ }^{94}$.

Plant Functional Types: ecosys represents multiple canopy and soil layers allowing for mechanistic Plant Functional Type (PFT) competition for light, water, and nutrients. The model represents various PFT traits that are distinct between plants, including specific leaf area, leaf clumping, turnover, optical properties, foliar nutrient content and retention, and root hydraulic conductivity ${ }^{39}$. Differences in growth rate and nutrient acquisition and conservation strategies drive different competitive strategies, through differential allocation of non-structural carbon, nitrogen, and phosphorus to different plant organs dependent on $\mathrm{PFT}^{91}$. This allocation determines leaf area, canopy height, and belowground allocation patterns, which, in turn, determine interception of direct and diffuse radiation across each canopy layer, and competition for nutrients and water through allocation to roots, which shapes their length and density. Nutrient competition is further influenced by belowground allocation to mycorrhizal fungi. Most PFTs engage fungal partners, many explicitly as mycorrhizae, which exchange soil nutrients (e.g., $\mathrm{N}$ and $\mathrm{P}$ ) for photosynthetic carbon. Mycorrhizae have larger surface area to volume ratios than plant roots, enabling greater uptake of soil nutrients and water.

The collection of traits determines competition between different PFTs for light and nutrients through the allocation and investment of carbon in leaves, stems, and roots. Four PFTs are represented in the current study based on previous observations from the Anaktuvuk River site: graminoids (similar to Eriophorum vaginatum), evergreen shrubs (Ledum palustre), deciduous shrubs (Betula nana), and nitrogen-fixing mosses (Hylocomium splendens). A full account of the different traits associated with these PFTs has been published recently ${ }^{39}$. Briefly, the deciduous shrubs are represented as having a greater specific leaf area and lower leaf clumping than evergreen shrubs, leading to greater light interception. The deciduous shrubs all have full annual leaf turnover, whereas evergreen shrubs retain their leaves year-round. Nutrient conservation under litterfall is driven by carbon, nitrogen, and phosphorus recycling coefficients, which increase with non-structural $\mathrm{C}: \mathrm{N}$ ratios ${ }^{91}$. Higher nutrient remobilization $(\mathrm{N}$ and $\mathrm{P})$ is modeled for evergreen shrubs relative to deciduous shrubs, allowing evergreens to better compete in nutrient limited environments ${ }^{45,63}$. 
Evergreen shrubs are represented as the most conservative PFT, with a relatively slow water uptake due to higher axial hydraulic resistance, slower leaf turnover, and slower plant growth. By contrast, deciduous shrubs have faster nitrogen and water uptake, due to a lower axial resistivity, resulting in a less conservative and more rapid growth strategy relative to evergreen shrubs $^{39,63}$. Deciduous shrubs are also better competitors under more nutrient rich conditions, but have a more rapid leaf turnover. However, the leaf nutrient concentrations are dynamic and dependent on nutrient availability, which feeds back onto modeled carboxylation rates and electron transport. Greater investment in nutrient uptake drives higher $\mathrm{CO}_{2}$ fixation rate in deciduous, relative to evergreen, shrubs ${ }^{35}$.

Model initialization and testing: We first initialized the model at the Anaktuvuk River site using published data for soil and vegetation properties ${ }^{15,17,23,41}$. Eleven soil layers were represented to a depth of $2 \mathrm{~m}$. Soil properties across the soil layers were initialized with attributes from the

602 Unified North America Soil Map (UNASM) ${ }^{98}$, and measured site specific values for edaphic vegetation $^{17}$. Soil organic carbon was initialized with the Northern Circumpolar Soil Carbon Database (NCSCD) ${ }^{1}$, with additional input from recent publications ${ }^{15}$.

Model simulations: To produce a realistic starting ecosystem state, spin-up simulations were run from 1900 - 2000 under dynamic climate, atmospheric $\mathrm{CO}_{2}$ concentrations ${ }^{99}$, and nitrogen deposition $^{100}$. The atmospheric forcing data (i.e., air temperature, precipitation, downward shortwave radiation, relative humidity, and wind speed) for each site were taken from the North American Regional Reanalysis (NARR), a long-term weather dataset originally produced at the National Oceanic and Land Administration (NOAA) National Centers for Environmental Prediction (NCEP) Global Reanalysis ${ }^{101}$. Where possible these model drivers were supplemented by site-specific data. The fire and climate perturbations, starting in 2000 following spin-up, were derived from the representative concentration pathways 8.5 (RCP8.5) scenario obtained from ensemble projections, downscaled and averaged from 15 CMIP models. RCP8.5 is broadly consistent with global emissions between 2006 and 2017. Fire disturbances were prescribed either in 2007 or 2080 during the RCP8.5 scenario (Table 1). The modeled depths of burn and extent of organic matter combustion for six fire severity scenarios were taken from a previously published dataset ${ }^{102}$ (Table 1).

Table 1: Perturbation scenarios over the $21^{\text {st }}$ Century. ${ }^{1}$ All simulations are run between 1900 to 6222100 , and the fire is initiated in the first year of each focal length period. The analyses below 623 may represent a focal length of 20 -years post-fire, or out to $2100 .{ }^{2} \mathrm{CF}$ : Climate Forcing: 624 represents the predicted changes in air temperature, radiative forcing, precipitation, atmospheric $625 \mathrm{CO}_{2}$, relative humidity, and atmospheric deposition of reactive nitrogen species $\left(\mathrm{NO}_{3}{ }^{-}, \mathrm{NH}_{4}{ }^{+}\right)$ 626 under an RCP8.5 climate scenario.

\begin{tabular}{|c|c|c|c|c|}
\hline$\underline{\text { Scenario name }}$ & Perturbation & Depth of burn & $\frac{\% \mathrm{OM}}{\text { combustion }}$ & $\underline{\text { Year of fire }}^{1}$ \\
\hline RCP8.5-no_fire & $\mathrm{CF}^{2}$ & $\mathrm{~N} / \mathrm{A}$ & $\mathrm{N} / \mathrm{A}$ & N/A \\
\hline Mild 1 & $\mathrm{CF}+$ Fire & $5 \mathrm{~cm}$ & $25 \%$ & 2007 \\
\hline Mild 2 & $\mathrm{CF}+$ Fire & $5 \mathrm{~cm}$ & $25 \%$ & 2080 \\
\hline Moderate 1 & $\mathrm{CF}+$ Fire & $11 \mathrm{~cm}$ & $50 \%$ & 2007 \\
\hline
\end{tabular}


Table 2: Years $2071-2100$ average seasonal increases relative to current values (1981-2010) in maximum and minimum temperatures, precipitation, and atmospheric $\mathrm{CO}_{2}$ concentration $\left(C_{\mathrm{a}}\right)$ under a RCP8.5 emission scenario downscaled and averaged across 15 CMIP5 models for the Anaktuvik River, Alaska gridcell.

\begin{tabular}{|c|c|c|c|c|}
\hline & $\frac{\text { Max. Temp. }}{\left({ }^{\circ} \mathrm{C}\right)}$ & $\frac{\text { Min. Temp. }}{\left(\underline{\left.{ }^{\circ} \mathrm{C}\right)}\right.}$ & Precipitation & $\underline{C_{a}}$ \\
\hline $\begin{array}{l}\text { Winter } \\
\text { (DJF) }\end{array}$ & 10.97 & 12.80 & 1.34 & 2.37 \\
\hline $\begin{array}{l}\text { Spring } \\
\text { (MAM) }\end{array}$ & 7.08 & 8.28 & 1.52 & 2.37 \\
\hline $\begin{array}{c}\text { Summer } \\
(\mathrm{JJA})\end{array}$ & 4.53 & 4.84 & 1.28 & 2.37 \\
\hline $\begin{array}{l}\text { Autumn } \\
\text { (SON) }\end{array}$ & 7.25 & 8.30 & 1.34 & 2.37 \\
\hline
\end{tabular}

634 Statistical analysis: The correlation between observational benchmarks and site simulations were 635 assessed using a root mean square error test. Significant differences between variables (e.g., 636 changes in soil carbon, net primary productivity, etc.) were tested using an analysis of variance test. Finally, we used an information theory approach (transfer entropy; ${ }^{43}$ ) to examine directional impacts from one variable (e.g., soil nutrient cycling) to another (e.g., net primary productivity). These relationships were inferred by Shannon information entropy $(\mathrm{H})$ and its transfer (TE) (unit bits), as previously described ${ }^{103}$.

$$
\begin{gathered}
H=-\sum_{i=1}^{n} p\left(x_{i}\right) \log _{2} p\left(x_{i}\right) \\
T_{X \rightarrow Y}=\sum_{y_{i}, y_{i-1}, x_{i-j}} p\left(y_{i}, y_{i-1}, x_{i-j}\right) \log _{2} \frac{p\left(y_{i} \mid y_{i-1}, x_{i-j}\right)}{p\left(y_{i} \mid y_{i-1}\right)}
\end{gathered}
$$

where $\mathrm{p}(\mathrm{x})$ is Probability Density Function (PDF) of $\mathrm{x}, \mathrm{p}\left(\mathrm{y}_{\mathrm{i}}, \mathrm{y}_{\mathrm{i}-1}, \mathrm{x}_{\mathrm{i}-\mathrm{j}}\right)$ is the joint PDF of the 644 current time step $\mathrm{y}_{\mathrm{i}}$, previous time step of $\mathrm{y}_{\mathrm{i}}$, and $j$ th time step before $\mathrm{x}_{\mathrm{i}} \cdot \mathrm{p}\left(\mathrm{y}_{\mathrm{i}} \mid \mathrm{y}_{\mathrm{i}-1}, \mathrm{x}_{\mathrm{i}-\mathrm{j}}\right)$ and $\mathrm{p}\left(\mathrm{y}_{\mathrm{i}} \mid\right.$ $645 \mathrm{y}_{\mathrm{i}-1}$ ) denote conditional PDF of the corresponding variables. For example, the information 646 entropy transfer from plant photosynthesis processes to soil heterotrophic respiration processes 
$647\left(\mathrm{R}_{\mathrm{H}}\right)$ is then calculated as Shannon entropy reduction (uncertainty reduction) of present $\mathrm{R}_{\mathrm{H}}$ given 648 the historical net primary productivity (NPP) records and also excluded the influence from 649 previous time step $\mathrm{R}_{\mathrm{H}}$. The significant threshold of transfer entropy from GPP to $\mathrm{R}_{\mathrm{H}}$ is identified 650 by first randomly shuffling NPP and $R_{H}$ time series, then calculating the shuffled transfer 651 entropy, assuming the randomly shuffled breaks the dependency between NPP and $\mathrm{R}_{\mathrm{H}}$. Variables 652 included in this analysis are NPP, nutrient concentrations $\left(\mathrm{NH}_{4}{ }^{+}, \mathrm{NO}_{3}{ }^{-}, \mathrm{PO}_{4}{ }^{3-}\right)$, plant nutrient 653 uptake, soil carbon concentration, total microbial biomass, aerobic heterotrophic biomass $(0.1$

654 and $0.5 \mathrm{~m})$, saprotrophic biomass $(0.1$ and $0.5 \mathrm{~m})$, air temperature, soil temperature, soil moisture 655 content $(0.1,0.5,0.85 \mathrm{~m})$, active layer depth, and snowpack depth.

656 Acknowledgements: This research was supported by the Director, Office of Science, Office of 657 Biological and Environmental Research of the U.S. Department of Energy under contract DE658 AC02-05CH11231 to Lawrence Berkeley National Laboratory as part of the Next-Generation 659 Ecosystem Experiments in the Arctic (NGEE Arctic) project.

660 Data/ Code availability: The ecosys model is available for download, 661 https://github.com/jinyun1tang/ECOSYS, while the scripts used to generate the figures and 662 analyze the data are publicly available at the ESS-DIVE repository (https://ess-dive.lbl.gov/) 663 at https://doi.org/10.15485/1670465.

664

665

666

\section{References:}

1. Hugelius, G. et al. A new data set for estimating organic carbon storage to $3 \mathrm{~m}$ depth in soils of the northern circumpolar permafrost region. Earth Syst. Sci. Data 5, 393-402 (2013).

2. Hugelius, G. et al. Estimated stocks of circumpolar permafrost carbon with quantified uncertainty ranges and identified data gaps. Biogeosciences 11, 6573-6593 (2014).

3. Mishra, U. et al. Spatial heterogeneity and environmental predictors of permafrost region soil 671 organic carbon stocks. Sci. Adv. 7, eaaz5236 (2021).

672 4. Serreze, M. C. \& Barry, R. G. Processes and impacts of Arctic amplification: A research 673 synthesis. Global and Planetary Change 77, 85-96 (2011).

674 5. Xiao, J. \& Zhuang, Q. Drought effects on large fire activity in Canadian and Alaskan forests.

$675 \quad$ Environ. Res. Lett. 2, 044003 (2007).

676 6. Higuera, P. E. \& Abatzoglou, J. T. Record-setting climate enabled the extraordinary 2020 fire 677 season in the western United States. Glob Change Biol gcb.15388 (2020) 678 doi:10.1111/gcb.15388. 
7. Ziel, R. H. et al. A Comparison of Fire Weather Indices with MODIS Fire Days for the Natural 680 Regions of Alaska. Forests 11, 516 (2020).

681 8. Chen, Y. et al. Future increases in Arctic lightning and fire risk for permafrost carbon. Nat.

682 Clim. Chang. (2021) doi:10.1038/s41558-021-01011-y.

683 9. Holloway, J. E. et al. Impact of wildfire on permafrost landscapes: A review of recent

684 advances and future prospects. Permafrost and Periglac Process ppp.2048 (2020)

685 doi:10.1002/ppp.2048.

686 10. Kim, J.-S., Kug, J.-S., Jeong, S.-J., Park, H. \& Schaepman-Strub, G. Extensive fires in

687 southeastern Siberian permafrost linked to preceding Arctic Oscillation. Science Advances 6, 688 eaax3308 (2020).

689 11. Veraverbeke, S. et al. Lightning as a major driver of recent large fire years in North 690 American boreal forests. Nature Clim Change 7, 529-534 (2017).

691 12. Rocha, A. V. et al. The footprint of Alaskan tundra fires during the past half-century: 692 implications for surface properties and radiative forcing. Environ. Res. Lett. 7, 044039 (2012).

693 13. Iwahana, G. et al. Geomorphological and geochemistry changes in permafrost after the 6942002 tundra wildfire in Kougarok, Seward Peninsula, Alaska: PERMAFROST CHANGE 695 AFTER A TUNDRA FIRE. J. Geophys. Res. Earth Surf. 121, 1697-1715 (2016).

696 14. Michaelides, R. J. et al. Inference of the impact of wildfire on permafrost and active layer 697 thickness in a discontinuous permafrost region using the remotely sensed active layer 698 thickness (ReSALT) algorithm. Environ. Res. Lett. 14, 035007 (2019).

699 15. Mack, M. C. et al. Carbon loss from an unprecedented Arctic tundra wildfire. Nature 475, $700 \quad 489-492(2011)$.

701 16. Rodríguez-Cardona, B. M. et al. Wildfires lead to decreased carbon and increased 702 nitrogen concentrations in upland arctic streams. Sci Rep 10, 8722 (2020).

703 17. Bret-Harte, M. S. et al. The response of Arctic vegetation and soils following an 704 unusually severe tundra fire. Phil. Trans. R. Soc. B 368, 20120490 (2013). 
18. Taş, N. et al. Impact of fire on active layer and permafrost microbial communities and metagenomes in an upland Alaskan boreal forest. ISME J 8, 1904-1919 (2014).

19. Wardle, D. A. Long-Term Effects of Wildfire on Ecosystem Properties Across an Island 708 Area Gradient. Science 300, 972-975 (2003).

709 20. Frost, G. V. et al. Multi-decadal patterns of vegetation succession after tundra fire on the $710 \quad$ Yukon-Kuskokwim Delta, Alaska. Environ. Res. Lett. 15, 025003 (2020).

711 21. Heim, R. J. et al. Long-term effects of fire on Arctic tundra vegetation in Western Siberia. 712 http://biorxiv.org/lookup/doi/10.1101/756163 (2019) doi:10.1101/756163.

713 22. Racine, C. H., Johnson, L. A. \& Viereck, L. A. Patterns of Vegetation Recovery after 714 Tundra Fires in Northwestern Alaska, U.S.A. Arctic and Alpine Research 19, 461 (1987).

715 23. Jandt, R. R. et al. Findings of the Anaktuvuk River Fire Recovery Study, 2007-2011. 716 (2013).

717 24. Wills, A. J., Cranfield, R. J., Ward, B. G. \& Tunsell, V. L. Cryptogam Recolonization after 718 Wildfire: Leaders and Laggards in Assemblages? fire ecol 14, 65-84 (2018).

719 25. Hart, S. C., DeLuca, T. H., Newman, G. S., MacKenzie, M. D. \& Boyle, S. I. Post-fire 720 vegetative dynamics as drivers of microbial community structure and function in forest soils. 721 Forest Ecology and Management 220, 166-184 (2005).

722 26. Holden, S. R., Rogers, B. M., Treseder, K. K. \& Randerson, J. T. Fire severity influences 723 the response of soil microbes to a boreal forest fire. Environ. Res. Lett. 11, 035004 (2016).

724 27. Pressler, Y., Moore, J. C. \& Cotrufo, M. F. Belowground community responses to fire: 725 meta-analysis reveals contrasting responses of soil microorganisms and mesofauna. Oikos $726 \quad 128,309-327$ (2019).

727 28. Wan, S., Hui, D. \& Luo, Y. Fire effects on nitrogen pools and dynamics in terrestrial 728 ecosystems: A meta-analysis. Ecological Applications 11, 1349-1365 (2001).

729 29. Knicker, H. How does fire affect the nature and stability of soil organic nitrogen and 730 carbon? A review. Biogeochemistry 85, 91-118 (2007). 
731 30. Bárcenas-Moreno, G. \& Bååth, E. Bacterial and fungal growth in soil heated at different 732 temperatures to simulate a range of fire intensities. Soil Biology and Biochemistry 41, 25177332526 (2009).

734 31. Mabuhay, J. A., Nakagoshi, N. \& Isagi, Y. Soil microbial biomass, abundance, and 735 diversity in a Japanese red pine forest: first year after fire. Journal of Forest Research 11, $736 \quad 165-173(2006)$.

737 32. Hewitt, R. E., Bent, E., Hollingsworth, T. N., Chapin, F. S. \& Taylor, D. L. Resilience of $738 \quad$ Arctic mycorrhizal fungal communities after wildfire facilitated by resprouting shrubs.

739 Écoscience 20, 296-310 (2013).

740 33. Martin, A. C., Jeffers, E. S., Petrokofsky, G., Myers-Smith, I. \& Macias-Fauria, M. Shrub 741 growth and expansion in the Arctic tundra: an assessment of controlling factors using an 742 evidence-based approach. Environ. Res. Lett. 12, 085007 (2017).

743 34. Myers-Smith, I. H. et al. Shrub expansion in tundra ecosystems: dynamics, impacts and $744 \quad$ research priorities. Environ. Res. Lett. 6, 045509 (2011).

745 35. Mekonnen, Z. A. et al. Arctic tundra shrubification: a review of mechanisms and impacts 746 on ecosystem carbon balance. Environ. Res. Lett. 29 (2021).

747 36. Güsewell, S. \& Gessner, M. O. N : P ratios influence litter decomposition and 748 colonization by fungi and bacteria in microcosms. Functional Ecology 23, 211-219 (2009).

749 37. Strickland, M. S. \& Rousk, J. Considering fungal:bacterial dominance in soils - Methods, 750 controls, and ecosystem implications. Soil Biology and Biochemistry 42, 1385-1395 (2010).

751 38. Malik, A. A. et al. Soil Fungal:Bacterial Ratios Are Linked to Altered Carbon Cycling.

$752 \quad$ Front. Microbiol. 7, (2016).

753 39. Mekonnen, Z. A., Riley, W. J., Randerson, J. T., Grant, R. F. \& Rogers, B. M. Expansion 754 of high-latitude deciduous forests driven by interactions between climate warming and fire. $755 \quad$ Nat. Plants 5, 952-958 (2019). 
756 40. Hu, F. S. et al. Tundra burning in Alaska: Linkages to climatic change and sea ice 757 retreat. J. Geophys. Res. 115, G04002 (2010).

758 41. Jones, B. M. et al. Fire Behavior, Weather, and Burn Severity of the 2007 Anaktuvuk 759 River Tundra Fire, North Slope, Alaska. Arctic, Antarctic, and Alpine Research 41, 309-316 760 (2009).

761 42. Rocha, A. V. \& Shaver, G. R. Burn severity influences postfire $\mathrm{CO} 2$ exchange in arctic 762 tundra. Ecological Applications 21, 14 (2011).

763 43. Bouskill, N. J., Riley, W. J., Zhu, Q., Mekonnen, Z. A. \& Grant, R. F. Alaskan carbon764 climate feedbacks will be weaker than inferred from short-term experiments. Nat Commun $765 \quad 11,5798(2020)$.

766 44. Grant, R. F. Ecosystem $\mathrm{CO}_{2}$ and $\mathrm{CH}_{4}$ exchange in a mixed tundra and a fen within a 767 hydrologically diverse Arctic landscape: 2. Modeled impacts of climate change: $\mathrm{CO}_{2}$ and $\mathrm{CH}$ 7684 exchange in the arctic. J. Geophys. Res. Biogeosci. 120, 1388-1406 (2015).

769 45. Grant, R. F. Modelling changes in nitrogen cycling to sustain increases in forest 770 productivity under elevated atmospheric $\mathrm{CO}_{2}$ and contrasting site conditions.

771 Biogeosciences 10, 7703-7721 (2013).

772 46. Grant, R. F. et al. Mathematical Modelling of Arctic Polygonal Tundra with Ecosys : 1.

773 Microtopography Determines How Active Layer Depths Respond to Changes in Temperature 774 and Precipitation: Active Layer Depth in Polygonal Tundra. J. Geophys. Res. Biogeosci. 122, $775 \quad 3161-3173(2017)$.

776 47. Hu, F. S. et al. Arctic tundra fires: natural variability and responses to climate change.

777 Frontiers in Ecology and the Environment 13, 369-377 (2015).

778 48. Bowman, D. M. J. S. et al. Vegetation fires in the Anthropocene. Nat Rev Earth Environ $779 \quad \mathbf{1}, 500-515(2020)$. 
49. Davis, K. T. et al. Wildfires and climate change push low-elevation forests across a critical climate threshold for tree regeneration. Proc Natl Acad Sci USA 116, 6193-6198

782 (2019).

783 50. Mekonnen, Z. A., Riley, W. J. \& Grant, R. F. 21st century tundra shrubification could 784 enhance net carbon uptake of North America Arctic tundra under an RCP8.5 climate 785 trajectory. Environ. Res. Lett. 13, 054029 (2018).

786 51. McGuire, A. D. et al. Dependence of the evolution of carbon dynamics in the northern 787 permafrost region on the trajectory of climate change. Proc Natl Acad Sci USA 115, 3882$788 \quad 3887$ (2018).

789 52. Nadelhoffer, K. J., Giblin, A. E., Shaver, G. R. \& Laundre, J. A. Effects of Temperature 790 and Substrate Quality on Element Mineralization in Six Arctic Soils. Ecology 72, 242-253 $791 \quad$ (1991).

792 53. Mekonnen, Z. A., Riley, W. J., Grant, R. F. \& Romanovsky, V. E. Changes in 793 precipitation and air temperature contribute comparably to permafrost degradation in a 794 warmer climate. Environ. Res. Lett. 16, 024008 (2021).

795 54. Monteux, S. et al. Long-term in situ permafrost thaw effects on bacterial communities 796 and potential aerobic respiration. ISME J 12, 2129-2141 (2018).

797 55. Keuper, F. et al. A frozen feast: thawing permafrost increases plant-available nitrogen in 798 subarctic peatlands. Glob Change Biol 18, 1998-2007 (2012).

799 56. Keuper, F. et al. Experimentally increased nutrient availability at the permafrost thaw 800 front selectively enhances biomass production of deep-rooting subarctic peatland species. 801 Glob Change Biol 23, 4257-4266 (2017).

802 57. Pedersen, E. P., Elberling, B. \& Michelsen, A. Foraging deeply: Depth-specific plant 803 nitrogen uptake in response to climate-induced $\mathrm{N}$-release and permafrost thaw in the High 804 Arctic. Glob Change Biol 26, 6523-6536 (2020). 
805 58. Hewitt, R. E. et al. Mycobiont contribution to tundra plant acquisition of permafrost-

806 derived nitrogen. New Phytol 226, 126-141 (2020).

807 59. Schuur, E. A. G., Crummer, K. G., Vogel, J. G. \& Mack, M. C. Plant Species

808 Composition and Productivity following Permafrost Thaw and Thermokarst in Alaskan

809 Tundra. Ecosystems 10, 280-292 (2007).

810 60. Bjorkman, A. D. et al. Plant functional trait change across a warming tundra biome.

$811 \quad$ Nature 562, 57-62 (2018).

812 61. Hudson, J. M. G. \& Henry, G. H. R. Increased plant biomass in a High Arctic heath

813 community from 1981 to 2008 . Ecology $90,2657-2663$ (2009).

814 62. Wilson, S. D. \& Nilsson, C. Arctic alpine vegetation change over 20 years. Global

815 Change Biology 15, 1676-1684 (2009).

816 63. Aerts, R. The advantages of being evergreen. Trends in Ecology \& Evolution 10, 6 817 (1995).

818 64. Vowles, T. \& Björk, R. G. Implications of evergreen shrub expansion in the Arctic. J Ecol $819 \quad 107,650-655(2019)$.

$820 \quad 65 . \quad$ Sturm, M., Racine, C. \& Tape, K. Increasing shrub abundance in the Arctic. Nature 411, $821 \quad 546-547(2001)$.

822 66. Natali, S. M. et al. Large loss of $\mathrm{CO} 2$ in winter observed across the northern permafrost 823 region. Nat. Clim. Chang. 9, 852-857 (2019).

824 67. Sullivan, P. F., Stokes, M. C., McMillan, C. K. \& Weintraub, M. N. Labile carbon limits 825 late winter microbial activity near Arctic treeline. Nat Commun 11, 4024 (2020).

826 68. Mack, M. C., Schuur, E. A. G., Bret-Harte, M. S., Shaver, G. R. \& Chapin, F. S.

827 Ecosystem carbon storage in arctic tundra reduced by long-term nutrient fertilization. Nature $828 \quad 431,440-443(2004)$. 
829 69. Bowman, W. D., Theodose, T. A., Schardt, J. C. \& Conant, R. T. Constraints of Nutrient 830 Availability on Primary Production in Two Alpine Tundra Communities. Ecology 74, 20858312097 (1993).

832 70. Abbott, B. W. et al. Tundra wildfire triggers sustained lateral nutrient loss in Alaskan 833 Arctic. Glob Change Biol gcb.15507 (2021) doi:10.1111/gcb.15507.

834 71. Lutsch, E. et al. Unprecedented Atmospheric Ammonia Concentrations Detected in the 835 High Arctic From the 2017 Canadian Wildfires. J. Geophys. Res. Atmos. 124, 8178-8202 836 (2019).

837 72. Rastetter, E. B. et al. Ecosystem Recovery from Disturbance is Constrained by N Cycle 838 Openness, Vegetation-Soil N Distribution, Form of N Losses, and the Balance Between

839 Vegetation and Soil-Microbial Processes. Ecosystems (2020) doi:10.1007/s10021-020$840 \quad 00542-3$.

841 73. Bormann, F. H. \& Likens, G. E. Catastrophic Disturbance and the Steady State in 842 Northern Hardwood Forests: A new look at the role of disturbance in the development of 843 forest ecosystems suggests important implications for land-use policies. American Scientist $844 \quad 67,660-669(1979)$.

845 74. Lovett, G. M. et al. Nutrient retention during ecosystem succession: a revised conceptual 846 model. Front Ecol Environ 16, 532-538 (2018).

847 75. Whitman, T. et al. Soil bacterial and fungal response to wildfires in the Canadian boreal 848 forest across a burn severity gradient. Soil Biology and Biochemistry 138, 107571 (2019).

849 76. Schimel, J. P., Kielland, K. \& Chapin, F. S. Nutrient Availability and Uptake by Tundra 850 Plants. in Landscape Function and Disturbance in Arctic Tundra (eds. Reynolds, J. F. \& 851 Tenhunen, J. D.) vol. 120 203-221 (Springer Berlin Heidelberg, 1996).

852 77. Shaver, G. R. et al. Global Change and the Carbon Balance of Arctic Ecosystems.

853 BioScience 42, 433-441 (1992). 
854 78. Tierney, J. A., Hedin, L. O. \& Wurzburger, N. Nitrogen fixation does not balance fire-

855 induced nitrogen losses in longleaf pine savannas. Ecology 100, (2019).

856 79. Wong, M. Y. et al. Biological Nitrogen Fixation Does Not Replace Nitrogen Losses After

857 Forest Fires in the Southeastern Amazon. Ecosystems 23, 1037-1055 (2020).

858 80. Norman, J. S. \& Friesen, M. L. Complex N acquisition by soil diazotrophs: how the ability

859 to release exoenzymes affects $\mathrm{N}$ fixation by terrestrial free-living diazotrophs. ISME J 11, $860 \quad 315-326(2017)$.

861 81. Liu, X.-Y. et al. Nitrate is an important nitrogen source for Arctic tundra plants. Proc Natl $862 \quad$ Acad Sci USA 115, 3398-3403 (2018).

863 82. Ball, P. N., MacKenzie, M. D., DeLuca, T. H. \& Holben, W. E. Wildfire and Charcoal 864 Enhance Nitrification and Ammonium-Oxidizing Bacterial Abundance in Dry Montane Forest 865 Soils. Journal of Environmental Quality 39, 11 (2010).

866 83. Kurth, V. J., Hart, S. C., Ross, C. S., Kaye, J. P. \& Fulé, P. Z. Stand-replacing wildfires 867 increase nitrification for decades in southwestern ponderosa pine forests. Oecologia 175, $868 \quad 395-407$ (2014).

869 84. Stephan, K., Kavanagh, K. L. \& Koyama, A. Comparing the Influence of Wildfire and 870 Prescribed Burns on Watershed Nitrogen Biogeochemistry Using 15N Natural Abundance in 871 Terrestrial and Aquatic Ecosystem Components. PLoS ONE 10, e0119560 (2015).

872 85. Rustad, L. et al. A meta-analysis of the response of soil respiration, net nitrogen

873 mineralization, and aboveground plant growth to experimental ecosystem warming.

874 Oecologia 126, 543-562 (2001).

875 86. Xue, K. et al. Tundra soil carbon is vulnerable to rapid microbial decomposition under 876 climate warming. Nature Clim Change 6, 595-600 (2016).

877 87. Schimel, J. P. \& Bennett, J. NITROGEN MINERALIZATION: CHALLENGES OF A 878 CHANGING PARADIGM. Ecology 85, 591-602 (2004). 
88. Sorensen, P. O. et al. The Snowmelt Niche Differentiates Three Microbial Life Strategies

880 That Influence Soil Nitrogen Availability During and After Winter. Front. Microbiol. 11, 871

881 (2020).

882 89. Bilbrough, C. J., Welker, J. M. \& Bowman, W. D. Early Spring Nitrogen Uptake by Snow-

883 Covered Plants: A Comparison of Arctic and Alpine Plant Function under the Snowpack.

884 Arctic, Antarctic, and Alpine Research 32, 404-411 (2000).

885 90. Kwon, M. J. et al. Drainage enhances modern soil carbon contribution but reduces old

886 soil carbon contribution to ecosystem respiration in tundra ecosystems. Glob Change Biol 25, 887 1315-1325 (2019).

888 91. Mekonnen, Z. A., Riley, W. J. \& Grant, R. F. Accelerated Nutrient Cycling and Increased

889 Light Competition Will Lead to 21st Century Shrub Expansion in North American Arctic

890 Tundra. J. Geophys. Res. Biogeosci. 123, 1683-1701 (2018).

891 92. Grant, R. F. Simulation of ecological controls on nitrification. Soil Biology and

892 Biochemistry 26, 305-315 (1994).

893 93. Grant, R. F. Simulation of methanotrophy in the mathematical model ecosys. Soil

894 Biology and Biochemistry 11 (1999).

895 94. Grant, R. F. \& Rochette, P. (1994) Soil Microbial Respiration at Different Water

896 Potentials and Temperatures: Theory and Mathematical Modeling. SOIL SCI. SOC. AM. J.

$897 \quad 58,10(1994)$.

898 95. Grant, R. F., Juma, N. G. \& McGill, W. B. Simulation of carbon and nitrogen

899 transformations in soil: Mineralization. Soil Biology and Biochemistry 25, 1317-1329 (1993).

900 96. Schmidt, M. W. I. et al. Persistence of soil organic matter as an ecosystem property.

$901 \quad$ Nature 478, 49-56 (2011).

902 97. Mouginot, C. et al. Elemental stoichiometry of Fungi and Bacteria strains from grassland 903 leaf litter. Soil Biology and Biochemistry 76, 278-285 (2014). 
904 98. Liu, S. et al. The Unified North American Soil Map and its implication on the soil organic 905 carbon stock in North America. Biogeosciences 10, 2915-2930 (2013).

906 99. Meinshausen, M. et al. The RCP greenhouse gas concentrations and their extensions 907 from 1765 to 2300. Climatic Change 109, 213-241 (2011).

908 100. Dentener, F. et al. Nitrogen and sulfur deposition on regional and global scales: A 909 multimodel evaluation: MULTIMODEL GLOBAL DEPOSITION. Global Biogeochem. Cycles

$910 \quad 20$, n/a-n/a (2006).

911 101. Kalnay, E. et al. The NCEP/ NCAR 40-Year Reanalysis Project. Bulletin of the American 912 Meteorological Society 77, 437-471 (1996).

913 102. Turetsky, M. R. et al. Recent acceleration of biomass burning and carbon losses in

$914 \quad$ Alaskan forests and peatlands. Nature Geosci 4, 27-31 (2011).

915 103. Ruddell, B. L. \& Kumar, P. Ecohydrologic process networks: 1. Identification:

916 ECOHYDROLOGIC PROCESS NETWORKS, 1. Water Resour. Res. 45, (2009). 


\section{Supplementary Files}

This is a list of supplementary files associated with this preprint. Click to download.

- BouskillEcosyssupplementaldraft3.docx 